\title{
Put to the Test
}

\section{The folk-tale motif of the "test to prove worthiness" in three of Shakespeare's comedies}

\section{Philippa Nicoll Antipas}

A thesis submitted to the Victoria University of Wellington in fulfillment of the requirements for the degree of Masters of Arts in English Literature.

\section{Victoria University}




\begin{abstract}
Critics have recognised folk-tales as being among the varied sources Shakespeare has mined for the plots of his plays. However, this recognition has often formed the basis of an argument which seeks to excuse what are perceived as flaws in Shakespeare's plays, for example claiming that humanised characters jostle against their folk-tale or popular culture archetypes, or that friction is generated when a folk-tale plot is placed into a realistic setting. There has been little examination of Shakespeare's relationship to his sources from folk-tale, and so in this thesis I use the motif of the "test imposed to prove worthiness" (Stith Thompson's Motif H900) as an example of the way Shakespeare develops, doubles and ultimately subverts these sources. I examine three comedies which employ this motif: The Taming of the Shrew, The Merchant of Venice and All's Well That Ends Well. In the first play I argue that the testing of Katherina's obedience rebounds to test Petruccio's masculinity. In The Merchant, I argue that the casket test and doubled ring test play a crucial role in the development of Bassanio's worthiness and loyalty, simultaneously casting doubt on Portia's faithfulness. Finally, in relation to All's Well, I argue that the test motif and by extension its folk-tale sources are subverted so that the impossible tasks rebound not only on Bertram, but on the play as a whole, testing the genres of romance and realism. I find that testing cycles have a structural function as they fall between the couples' weddings and consummations. Because of this placement, they are linked to private and public anxieties about sexuality and fidelity, in turn demonstrating their thematic function. The development, doubling and subversion of folk-tales allow Shakespeare to explore ideas fully, often contrapuntally. Thus, my thesis seeks to address the gap in the critical studies by contending that Shakespeare makes innovative use of his folk-tale sources. While ambiguity is certainly generated in each of the three plays, this is a deliberate effect rather than a flaw; no apology is required.
\end{abstract}




\section{Acknowledgements}

I like to recognise the high school teachers who initially sparked my love of Shakespeare: Mrs Fitzgerald, Mr Plant, Mrs Kay.

I owe a debt of gratitude to Dr Mark Houlahan for his mentorship, and to Dr Geoff Miles for his invaluable support and advice.

For Mum and Dad and Chris, and especially for Tony who is my greatest champion.

"Thanks, sir; all the rest is mute."

(All's Well That Ends Well, 2.3.77) 


\section{Table of Contents}

Chapter One: $\quad$ Once Upon a Time: An Introduction ........................................... 7

Chapter Two: $\quad$ The Shrew who turned into a Wife: The Taming of the Shrew........ 29

Chapter Three: $\quad$ The Princess and the Ring: The Merchant of Venice ......................... 45

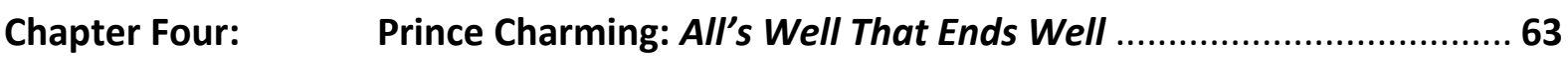

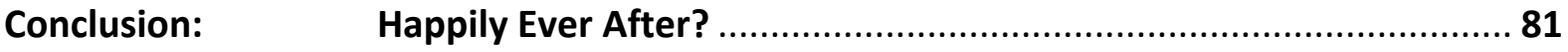

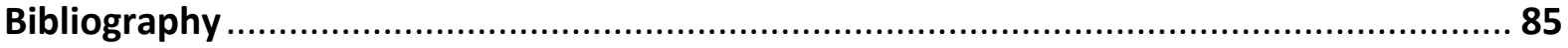




\section{Chapter One \\ Once Upon a Time: An Introduction}

Once upon a time William Shakespeare was brought up in rural Warwickshire, surrounded by forest and farms and folk-tales. Once upon a time William Shakespeare was a grammar school student reading, studying and coming to love Ovid. Ovid's maxim of "everything changes, nothing is lost" $^{1}$ seems to have been taken by Shakespeare as a guiding principle in his use of source materials. He incorporates oral and literary sources, re-shaping them to formulate his plays. The ways in which Shakespeare has metamorphosed specific folk-tale motifs, and how these transformations are representative of the concerns dramatised in his plays, have been largely ignored by critics. My thesis seeks to address this omission.

In the Beginning: Definitions

Defining what constitutes a 'folk-tale' can be problematic. The key distinction to establish is that between a folk- and a fairy-tale. I follow folklorist Stith Thompson's generally accepted definition which regards 'folk-tale' as an umbrella term under which sit subgenres such as the fairy-tale. Folk-tales come from an oral storytelling tradition and are realistic short stories which tend to be grounded in everyday life so can be violent or bawdy. ${ }^{2}$ On the other hand, fairy-tales almost always have a magical element to them. Even though tales have their origin in oracy, it is essentially impossible to separate oral from written material because of the fluid, overlapping relationship between them and so for Thompson, folk-tales include texts such as ballads, novellas and drama. ${ }^{3}$

\footnotetext{
${ }^{1}$ A. S. Kline, “Ovid's Metamorphoses." Trans. Anthony S. Kline, 2000. Web. 19 December 2012. <http://ovid.lib.virginia.edu/trans/Ovhome.htm>.

${ }^{2}$ See Melinda Dahl, Stefanie Kelly, Dale Ray and Sheila Sweeney, “Once Upon a Time: Four Familiar Folk and Fairy Tales." n.d. Web. 16 February 2012. <http://cuip.uchicago.edu/wit/2000/teams/onceupon/whatisit.html>.

${ }^{3}$ Stith Thompson, The Folktale (New York: Holt, Rinehart and Winston, 1946), 5.
} 
Folk-tales have been catalogued in order to identify their underlying structures and to form a basis from which they may be compared. Borrowing the concept from the biological sciences, several folklorists have formulated a morphology of folk-tales, most notably Antti Aarne, whose work was then revised twice by Thompson and again more recently and extensively by Hans-Jörg Uther; and Vladimir Propp. Aarne/Thompson/Uther examined folk-tales in terms of their tale types and common motifs. Aarne and Thompson "noticed recurrent characters, settings, incidents, and events that 'keep on being used by storytellers' and hence appear to be 'the stuff out of which tales are made'". ${ }^{4}$ They labelled this "stuff" a motif, which can be explained as "a small narrative unit recurrent in folk literature." ${ }^{5}$ Thompson's Motif-Index of Folk Literature identifies literally thousands of motifs, categorised into 23 groups including Group H: Tests. There are four general types of tests: identity tests, tests of cleverness, tests of prowess, and other tests. ${ }^{6}$

For Propp, who contested Aarne and Thompson's method, fairy-tales should be analysed in terms of their structure. He defined his morphology as "a description of the tale according to its component parts and the relationship of these components to each other and to the whole." ${ }^{7}$ His morphology consists of 31 steps that he argues most fairy-tales follow chronologically. In Propp's classification, testing occurs at steps 12 and 15 . While both morphologies have drawn criticism, ${ }^{8}$ it is clear that testing and the imposition of tasks are common to both systems and are therefore a folk-tale convention.

My thesis aims to explore Shakespeare's relationship to folk-tale sources by examining the role of the folk-tale test motif in three of Shakespeare's comedies: The Taming of the Shrew, The Merchant of Venice and All's Well That Ends Well. Not only do

\footnotetext{
${ }^{4}$ Thompson quoted in Robert A. Georges, "The Centrality in Folkloristics of Motif and Tale Type," Journal of Folklore Research 34.3 (1997), 203.

${ }^{5}$ Jane Garry and Hasan El-Shamy, eds., Archetypes and Motifs in Folklore and Literature: A Handbook (Armonk and London: M. E. Sharpe, 2005), xv.

${ }^{6}$ Stith Thompson, Motif-Index of Folk Literature: A Classification of Narrative Elements in Folk Tales, Ballads, Myths, Fables, Mediaeval Romances, Exempla, Fabliaux, Jest-Books, and Local Legends. (Bloomington: Indiana University Press, 1993). Web. 18 July 2011. <www.ruthenia.ru/folklore/thompson/index.htm>.

${ }^{7}$ V. Propp, Morphology of the Folktale. Trans. Laurence Scott, Second ed. (Austin and London: University of Texas Press, 1968), 19.

8 “In 1962 [Alan] Dundes expressed a similar viewpoint [to Propp], stating that the Tale Type Index and MotifIndex both are useful 'as bibliographic aids' but that they 'do not provide an adequate basis for comparative studies,'” Alan Dundes quoted in Georges 204. For a full discussion, see Georges 204-6. Also: "Propp limits his analysis to only one kind of folktale, that is, to fairy tales or Aarne-Thompson tale types 300-749," Alan Dundes' introduction to Propp, xiv.
} 
these three plays include the testing motif but they also contain specific tale types as identified by Aarne, Thompson and Uther (ATU). For example, The Taming of the Shrew is Tale Type 901, 'Taming of the Shrew', The Merchant of Venice contains Type 890, 'A Pound of Flesh' and All's Well That Ends Well has elements of Tale Type 891, 'The Man Who Deserted His Wife'. Because the plays reflect these tale types to varying degrees, it is more fruitful to focus on the motifs contained within them. Naturally there are more motifs than that of the test; however this is at the core of my argument.

To provide a basis for comparison I will examine the test motif in a general sense, under the Thompson category of Motif H900: 'Tasks Imposed'. In this motif characters are assigned certain tasks which may be difficult to achieve, and the purpose of completing the tasks is to escape a punishment or to receive a reward. ${ }^{9}$ The tasks may take the form of a quest, or simply be a test to determine what Thompson calls "prowess". This is a valuable approach to take in investigating the chosen texts, as characters within each play face this kind of challenge. In The Taming of the Shrew, for example, Katherina is subjected to Petruccio's wager on which husband has the most obedient wife; Bassanio must choose the correct casket in order to gain Portia's hand; and Helena's quest is to get her husband's family ring from his finger and to fall pregnant with his child. These tasks, and others in the texts, "function as tests of the hero, who must perform them in order to defeat evil, restore order, and/or achieve union with a woman (or man)."10

There is a subtle but crucial difference between a task and a test. According to the $O E D$, a task is "a piece of work imposed, exacted, or undertaken", or "in [a] more general sense ... something that one has to do (usually involving labour or difficulty)". ${ }^{11}$ And a test is "that by which the existence, quality, or genuineness of anything is or may be determined". ${ }^{12}$ In other words we can say that tasks are imposed in order to test someone, particularly in terms of verifying their prowess. While this word often has masculine connotations such as valour or bravery, the OED also notes broader synonyms such as

\footnotetext{
${ }^{9}$ Stith Thompson, Motif-Index of Folk Literature, CD-ROM. Ed. 1993

10 Jane Garry, "Quest, Motif H1200," Archetypes and Motifs in Folklore and Literature: A Handbook, eds. Jane Garry and Hasan El-Shamy (Armonk and London: M. E. Sharpe, 2005), 249.

${ }^{11}$ task, n. OED Online. December 2011. Web. 15 February 2012. <http://www.oed.com/view/Entry/198017>.

${ }^{12}$ test, n.1 OED Online. December 2011. Web. 15 February 2012. <http://www.oed.com/view/Entry/199677>.
} 
expertise or skill. ${ }^{13}$ In folk-tale tradition the completion of tasks by characters allows them to demonstrate their expertise in terms of their virtue or worthiness. ${ }^{14}$

Following Breadcrumbs: Critical Pathways

There are two main ways the relationship between Shakespeare, folklore and oral tradition has been explored by critics. The first is through festivity: the rites and cultural practices of holidays. This critical path emphasises ideas of inversion, saturnalia, and the movement from the court to the country or "green world". ${ }^{15}$ It often draws on Mikhail Bakhtin's concept of carnival. The most notable idea for me associated with this path is that of the Ovidian metamorphosis, as characters are transformed through their topsy-turvy experiences. The second way is the study of Shakespeare's use of fairy-tale creatures, particularly the ghosts, witches and fairies that inhabit Hamlet, Macbeth and A Midsummer Night's Dream, among other plays. ${ }^{16}$ From this tradition Kenneth Muir's general observation that Shakespeare combines literary and folk material ${ }^{17}$ is highly relevant to my thesis. However, aside from these broad brushstrokes, there appears to be a surprising gap in the critical studies, and a need to explore Shakespeare's use of folk-tales more closely.

We shall see that many scholars have remarked that Shakespeare draws from folktales as a source for his plays, but I have been unable to find anyone who has specifically examined the test motif as a model for his use of folk-tales. This is an omission, and one that deserves attention. Two general critical studies, both by Leah Scragg, ${ }^{18}$ have been formative for me in shaping an overall understanding of Shakespeare's use of recurring plot devices, and the relationship between these and the expectations an early modern audience

\footnotetext{
${ }^{13}$ prowess, n. OED Online. December 2011. Web. 22 February 2012.

<http://www.oed.com/view/Entry/153543>.

${ }^{14}$ For example 'The Twelve Dancing Princesses', further examples mentioned later.

${ }^{15}$ See C. L. Barber, Shakespeare's Festive Comedy: A Study of Dramatic Form and its Relation to Social Custom (New Jersey: Princeton University Press, 1959); Northrop Frye, "The Argument of Comedy," Shakespeare: An Anthology of Criticism and Theory 1945-2000, ed. Russ McDonald (Malden: Blackwell Publishing, 2004); François Laroque, Shakespeare's Festive World: Elizabethan Seasonal Entertainment and the Professional Stage (Cambridge: Cambridge University Press, 1991); Robert Weimann, Shakespeare and the Popular Tradition in the Theatre: Studies in the Social Dimension of Dramatic Form and Function. Trans. Robert Schwartz. (Baltimore: John Hopkins University Press, 1978).

${ }^{16}$ See Katharine M. Briggs, The Anatomy of Puck: An Examination of Fairy Beliefs among Shakespeare's Contemporaries and Successors (London: Routledge and Kegan Paul, 1959).

${ }^{17}$ Kenneth Muir, "Folklore and Shakespeare," Folklore 92.2 (1981), 232.

${ }^{18}$ Leah Scragg, Shakespeare's Mouldy Tales: Recurrent Plot Motifs in Shakespearian Drama (London and New York: Longman, 1992); Shakespeare's Alternative Tales (Harlow: Addison Wesley Longman, 1996).
} 
might have had when seeing these motifs in performance. While Scragg does discuss each of the three plays I focus on, neither book makes mention of the testing motif specifically; instead she focuses on plots such as the bed-trick, the cross-dressing female, or the feigned death. Scragg persuasively claims that such stock devices were imbued with "cultural baggage" ${ }^{19}$ for Shakespeare's audience and had become "encrusted with meanings" ${ }^{20}$ which demand consideration even though we may not now necessarily have an immediate understanding of them.

Jan Harold Brunvand has written both an article and a book ${ }^{21}$ looking at the relationship between the oral and literary versions of the 'Taming of the Shrew'. He is primarily interested in ATU Tale Type 901 rather than specific motifs, but argues convincingly that the oral tradition of this tale is a source for Shakespeare's play of the same name. Scholars follow Brunvand's path and emphasise the folk origins of The Taming of the Shrew, but generally do so defensively as if to apologise for the play's contents. We shall see that this is a common critical treatment of Shakespeare and folk-tale: that somehow Shakespeare's drawing on 'unliterary' sources leads his plays to become less convincing or realistic. Thus the problematic nature of The Shrew, encapsulated by the debate over Katherina's final 'submission' speech, dominates discussion. Margaret Lael Mikesell usefully describes this debate as being between "the seemingly incompatible notions of dominance and mutuality". ${ }^{22}$ Similarly, John C. Bean categorises the two competing perspectives as either 'revisionist', seeing Katherina's assertions as ironic, or the more traditional 'antirevisionist', arguing that the speech is in keeping with the play's intended farce. ${ }^{23}$ This argument over genre draws on the nature of the play's folk-tale origins. Those who contend that the play is farce highlight the humorous depiction of domestic violence as coming from folklore and part of popular culture in ballads. ${ }^{24}$ From the opposing view, Germaine Greer

\footnotetext{
${ }^{19}$ Scragg, Alternative Tales 3.

${ }^{20}$ Scragg, Alternative Tales 2.

${ }^{21}$ Jan Harold Brunvand, "The Folktale Origin of The Taming of the Shrew," Shakespeare Quarterly 17.4 (1996); The Taming of the Shrew: A Comparative Study of Oral and Literary Versions (New York and London: Garland Publishing, 1991).

22 Margaret Lael Mikesell, "'Love Wrought these Miracles': Marriage and Genre in The Taming of the Shrew," The Taming of the Shrew: Critical Essays, ed. Dana E. Aspinall (New York and London: Routledge, 2002 ), 107. 23 John C. Bean quoted in Karen Newman, "Renaissance Family Politics and Shakespeare's The Taming of the Shrew," English Literary Renaissance 16.1 (1986), 97.

${ }^{24}$ See Frances E. Dolan, The Taming of the Shrew: Texts and Contexts (New York: Bedford Books, 1996), 244. A modern example might be Punch and Judy.
} 
suggests that the play develops from its folk-tale origins to depict the "forging of a partnership between equals", ${ }^{25}$ and Bean concurs that the play starts to move away from farce and towards romantic comedy. ${ }^{26}$ Significantly though, Bean argues that the end of the play is characterised by a return to its folk sources, and this is the reason for its tension. He makes a connection between The Shrew and the later so-called problem comedies of Measure for Measure and All's Well That Ends Well, asserting that Shakespeare has placed a "humanised character" into a "dehumanising plot" which results in "incoherence". ${ }^{27}$ Thus we can indeed see that the folk sources of a play become a way to excuse what's seen as unpalatable in Shakespeare's dramaturgy rather than formulate a basis for analysis.

Critics have routinely commented on the folk-tale origins of The Merchant of Venice $^{28}$ placing emphasis on the lottery of the three caskets. C. L. Barber noted the connection between the casket plot and the thematic concerns of the play, ${ }^{29}$ a trend that has continued in scholarship. In particular, Joan Ozark Holmer has argued for the centrality of the casket test, saying that the "spirit" of the play is represented by the choice of the lead casket which symbolises "wise love". ${ }^{30}$ It is commonly observed that the choosing between the caskets speaks to the theme of not judging by appearances. ${ }^{31}$ The ring plot, which is a crucial additional test in the play, has been dismissed by Barber who argues that its only purpose is to reinforce the play's demonstration that "human relationships are stronger than their outward signs". ${ }^{32}$ However recent scholarship is beginning to acknowledge that in gaining Bassanio's ring, Portia tests her husband. ${ }^{33}$ Lawrence Danson comes closest to examining the function of the test motif as he sees that there are a series of "trials" in

\footnotetext{
${ }^{25}$ Greer quoted in Aspinall 11.

${ }^{26}$ John C. Bean, "Comic Structure and the Humanising of Kate in The Taming of the Shrew", The Woman's Part: Feminist Criticism of Shakespeare, eds. Gayle Green, Carolyn Ruth Swift Lenz, Carol Thomas Neely (Urbana: University of Illinois, 1980), 66.

${ }^{27}$ Bean 74-5.

${ }^{28}$ See Barber 169; Harley Granville-Barker, Prefaces to Shakespeare: Volume I: Hamlet, King Lear, The Merchant of Venice, Antony and Cleopatra, Cymbeline (London: B. T. Batsford, 1958), 335; John Drakakis, ed., The Merchant of Venice (London: Methuen Drama, 2010), 40; Christopher Spencer, The Genesis of Shakespeare's "Merchant of Venice" (New York: Edwin Mellen Press, 1988), 35.

${ }^{29}$ Barber 170, 174.

30 Joan Ozark Holmer, The Merchant of Venice: Choice, Hazard and Consequence (London: Macmillan Press, 1995), 45.

${ }^{31}$ See Catherine Belsey, "Love in Venice”, Shakespeare Survey 44, (1992), 44; Spencer 35.

32 Barber 186.

${ }^{33}$ Drakakis 92-3.
} 
Merchant which become "dramatic metaphors for love's harmony". ${ }^{34}$ Hansel and Gretellike, I have followed these breadcrumbs to examine the role played by Shakespeare's testing motif and thus his manipulation of folk-tales.

W.W. Lawrence's 1931 discussion of the folk-tale origins of All's Well That Ends Well has been influential in scholarship. ${ }^{35}$ His argument is that the play evolves from two tales: the 'Healing of the King' and the 'Fulfilment of the Tasks,' and that while Shakespeare does adapt his sources, altering details and developing realistic characterisations, he is ultimately faithful to folklore. Lawrence places Helena in the tradition of the 'Clever Wench' to emphasise her virtue which eventually wins Bertram over and allows the couple to have a happy ending. In doing so, Lawrence downplays the realistic elements in the play and attributes any tension in it to Shakespeare's desire to juxtapose Helena's worthiness against the corrupt society about her. Ensuing critics have then taken a position in relation to Lawrence, commonly arguing that the play is more than just the presentation of a fairy-tale problem that needs a fairy-tale solution. ${ }^{36}$ Instead they tend to root the play's tension in Shakespeare's inadequacy in imposing psychological realism on a romance plot, $^{37}$ as does Bean with The Taming of the Shrew.

This is an ongoing debate: what effect does the insertion of romance plots into realistic settings have on Shakespeare's plays? 'Romance' is itself a tricky term, but I follow the OED 3a definition as "a fictitious narrative, usually in prose, in which the settings or the events depicted are remote from everyday life, or in which sensational or exciting events or adventures form the central theme." ${ }^{38}$ Critics such as Bean cite the friction between the genres as the reason behind the tension generated. This observation has the potential to

\footnotetext{
${ }^{34}$ Lawrence Danson, The Harmonies of "The Merchant of Venice" (New Haven and London: Yale University Press, 1978), 118.

${ }^{35}$ W. W. Lawrence, Shakespeare's Problem Comedies (New York: Frederick Ungar Publishing, 1960).

${ }^{36}$ For example: H. C. Cole, The "All's Well" Story from Boccaccio to Shakespeare (Urbana: University of Illinois Press, 1981); G. K. Hunter, ed., All's Well That Ends Well (London: Cengage Learning, 2007); Sheldon P. Zitner, Twayne's New Critical Introductions to Shakespeare: "All's Well That Ends Well" (Boston: Twayne Publishers, 1989).

${ }^{37}$ See Nicholas Brooke, “All's Well That Ends Well”, Aspects of Shakespeare's 'Problem Plays': Articles Reprinted from "Shakespeare Survey", eds. Kenneth Muir and Stanley Wells (Cambridge: Cambridge University Press, 1982), 16; Hunter xxxiii; Zitner xx.

${ }^{38}$ Romance, n. and adj. 3a. OED Online. September 2012. Web. 14 November 2012.

<http://www.oed.com/view/Entry/167065>.
} 
become a convenient, short-hand answer, but by exploring the role the testing motif plays, I can offer a more substantive response.

This critical debate also provides context to Alexander Leggatt's excellent article which examines the way the two competing dramatic conventions of romance and realism are tested within All's Well. ${ }^{39}$ In so doing, Leggatt wrestles with the source of the tensions attributed to the text. While his main concern is about the testing of genre, calling the play an "important dramatic experiment", 40 Leggatt is one of the very few critics who have made specific mention of the test motif, saying that "the folk-tale task is a symbolic way of achieving the personal adjustment that reality requires." ${ }^{11}$ This has been highly significant in shaping my understanding of Shakespeare's use of the test motif in his adaption of folktale sources.

\section{Bedtime Stories: Shakespeare's Sources}

As I have shown, it has been well established that Shakespeare draws from folk-tales as sources for his plays. Although critics may disagree about sources for The Taming of the Shrew, there is consensus that the roots of the story come from folklore. For example, there is a broad folk tradition of the figure of the shrewish wife. Shakespeare's audiences would have been familiar with her from characters such as Noah's wife in the English mystery plays. Ballads like "A Merry Jest of a Shrewd and Curst Wife Lapped in Morel's Skin, for Her Good Behaviour" are a further indication of the folk tradition. Even the public spectacle of punishments for disobedient wives, for example the skimmington, stocks or the scold's bridle, would have reminded people of Mrs. Noah's antics and the consequences outspoken women faced. Thus scholars regularly place The Taming of the Shrew within this folk context. ${ }^{42}$

\footnotetext{
${ }^{39}$ Alexander Leggatt, “All's Well That Ends Well: The Testing of Romance," Modern Language Quarterly 32.1 (1971): 21-41.

40 Leggatt 40.

${ }^{41}$ Leggatt 31.

${ }^{42}$ See Bean 66; Geoffrey Bullough, ed. Narrative and Dramatic Sources of Shakespeare, Volume I: Early Comedies, Poems and Romeo and Juliet (London: Routledge and Kegan Paul, 1957), 61; Brunvand, "Folktale Origin" 346; Brunvand, Comparative Study 176; Dolan 244; Barbara Hodgdon, ed., The Taming of the Shrew (London: A \& C Black, 2012), 7.
} 
This confirms the shrewish wife as folk tradition, but does not address the testing motif itself nor the effect of adapting folklore. However, the motif circulated in relation to the tale of the 'Taming of the Shrew'. In Shakespeare's play the two key testing events are the absurd statements about the sun being the moon or an old man being a virgin that Katherina needs to agree with in Act 4, Scene 5; and the wager in Act 5. Brunvand argues that the wager has a "broader and older tradition" ${ }^{43}$ and as an independent motif has been linked to other tales. It does not always form part of the taming plot, and may have only started to be connected to Tale Type 901 around Shakespeare's time. ${ }^{44}$ Both Brunvand and Barbara Hodgdon discuss the likelihood of El Conde Lucanor, a collection of stories by Don Juan Manuel, as an analogue for the absurd statements Petruccio puts to Katherina. Brunvand states that it is unlikely that Shakespeare knew of this text ${ }^{45}$ whereas Hodgdon cautiously hedges her bets. ${ }^{46}$ Nevertheless, there was certainly a tradition of both the absurd statements and the wager being connected to the taming plot. Brunvand points to a Danish tale which links these plots together, arguing that this "clearly represents the kind of primary link which must have existed between Shakespeare and the popular tradition." ${ }^{47}$

Geoffrey Bullough, in his Narrative and Dramatic Sources of Shakespeare, lists the following texts as sources and analogues for The Taming of the Shrew: the problematic play Taming of a Shrew (1594?); S. Goulart's Thrésor D'histoires Admirables et Memorables (1606?); and Supposes (1566) by George Gascoigne. While offering Goulart's story of a beggar transformed into a lord as an analogue for the Induction scenes of The Shrew, Bullough also recognises the folk-tale origin of this plot, stating that an example of this motif occurs in The Arabian Nights. ${ }^{48}$ Gascoigne's Supposes is included as the most likely source of the Bianca plot with its multiple suitors and identity confusions. Bullough acknowledges the contentious relationship between Shakespeare's The Shrew and the anonymous $A$ Shrew without adopting a strong position, simply concluding that "A Shrew may not be so much the source-play as Shakespeare's first shot at the theme." 49

\footnotetext{
${ }^{43}$ Brunvand, Comparative Study 201.

${ }^{44}$ Brunvand, Comparative Study 14.

${ }^{45}$ Brunvand, Comparative Study 173.

46 "folk-tale or/and oral tradition may lie behind both tales," Hodgdon 60.

${ }^{47}$ Brunvand, Comparative Study 181. Tale outlined in "Folktale Origin" 350-1.

${ }^{48}$ Bullough 58.

${ }^{49}$ Bullough 58.
} 
There are important connections between these two plays. Both follow the same essential plotline, and contain the absurd statements and wager tests. Significantly, the way Shakespeare expands the testing in A Shrew mimics what he does generally with both the testing motif and sources from folklore. Shakespeare develops a broader scope of testing in his play. For example, between the absurd statements and the final wager is a scene where Katherina must kiss Petruccio in public. This continues the testing cycle Katherina is subjected to, but it does not occur in A Shrew. In the Induction, when the Lord sends for his page to play Sly's wife, the order is sent conditionally, in the form of a test. ${ }^{50}$ Furthermore, in order to gain Bianca's hand, Gremio and Tranio get into a 'bidding war', where each tries to outdo the other in terms of offering Baptista the most generous dowry. This is framed as a wager (see 2.1.345-8). None of these instances occur in A Shrew. Not only does Shakespeare take his testing motif from folk-tale, he develops it beyond his source material to suggest something about the direction his play may take.

This development is also evident in The Merchant of Venice where the pound of flesh, casket, and ring plots all have folk origins and are brought together in Shakespeare's play. The sources that Bullough records in his Narrative and Dramatic Sources for Merchant are: Il Pecorone (c. 1558) by Ser Giovanni Fiorentino; The Three Ladies of London (1584) a play by Robert Wilson; Alexander Silvayn's The Orator (1596); Zelauto or the Fountain of Fame (1580) by Anthony Munday; Christopher Marlowe's play The Jew of Malta (1589?); II Novellino of Masuccio; Confessio Amantis; and extracts from the Gesta Romanorum. Many critics argue that the direct source of the play may not be extant, ${ }^{51}$ and that Shakespeare may have not even had access to all or some of the texts listed above. ${ }^{52}$ With this questioning of Shakespeare's literary sources, the case for the contribution of folk-tales to The Merchant is made more compelling, and is also recognised by most critics. ${ }^{53}$

While Shakespeare's access to /l Pecorone cannot be proven, it does seem as though this text is a key source for The Merchant of Venice. The plot of the novella correlates

\footnotetext{
${ }^{50}$ See William Shakespeare, The Taming of the Shrew, ed. Barbara Hodgdon (London: A \& C Black, 2010). Ind.1.108-09. Quoted in this thesis on page 37. All subsequent references to this play will be from this edition and cited parenthetically.

${ }^{51}$ See J. Madison Davis and Sylvie L. F. Richards, "The Merchant and the Jew: A Fourteenth-Century French Analogue to The Merchant of Venice, Shakespeare Quarterly 36.1 (1985), 56; Spencer 4.

52 Davis and Richards 56.

53 See Barber 169; Davis and Richards 57; Drakakis 34, 40; Scragg, Mouldy Tales 50, 52; Spencer 4.
} 
closely to Shakespeare's play, including the pound of flesh plot, the cross-dressed lawyer who finds the loophole that saves the debtor, a testing cycle in relation to the Lady of Belmonte, and a ring plot. Notably, the casket plot does not form part of this story. The test in // Pecorone is an overtly sexual one, with the suitor needing to make love to the Lady - the trick to accomplishing this is not drinking the drugged refreshment prior to bed. The single exchange of rings between the Lady of Belmonte and her husband, which she then in disguise begs back as payment for legal services, and then as a wife accuses her new husband of losing, moves the story towards its simplistic 'happily ever after' conclusion. As in The Taming of the Shrew where the testing motif is developed, in The Merchant Shakespeare complicates his folk-tale sources. We will see that the addition of the casket test and the doubling of the ring plot allows him to add subtlety and richness to his work.

Bullough includes John Gower's Confessio Amantis and the Gesta Romanorum as likely sources of the casket plot. In the first text two knights choose between two identical chests. Because there are no distinguishing features on the chests, the test is one of fate: whom God deems to be the knight worthy of his just reward. In the latter, the casket test is more recognisable, with a shipwrecked princess having to choose between inscribed gold, silver and lead chests in order to prove her worthiness to be the Emperor's son's wife. In The Merchant of Venice, it is of course Portia's suitors who are put to this kind of test. As noted above some critics posit that the lead casket is of great significance, evolving into a central metaphor for the play. What Shakespeare does with this folk-tale is to make the testing far more protracted - while retaining its key purpose of proving worthiness - taking three acts until Bassanio chooses the correct lead casket, by which time both Portia and the audience know the contents of each. In a further development, Shakespeare also presents the test from several perspectives; thus we become aware that the casket lottery not only tests a suitor's character, but simultaneously tests Portia's will.

It is particularly Shakespeare's combination of the two main trials with their folk-tale origins, the pound of flesh plot and the casket plot, that should spark interest. For example, it would be informative to know when their blending first occurred. An in-depth Brunvandstyle analysis of these motifs would add to the existing body of knowledge. In the meantime, critics continue to 'source-hunt', for example, J. Madison Davis and Sylvie L. F. Richards argue for a French miracle play, Le Miracle de un Marchant et un Juif, as an 
analogue to The Merchant. While I find this unlikely, their overall point is significant: "Le Miracle hint[s] at a network of interrelating stories, folk tales, and early drama from which Shakespeare may have drawn, directly and indirectly". ${ }^{54}$ This point, an echo of Muir's, is made by other scholars ${ }^{55}$ and the fact that both the bond and casket plots are also identified ATU tale types strengthens my position that Shakespeare may well have encountered the basis for his play through oral sources.

As mentioned above, Lawrence has discussed the folk-tale origins of All's Well That Ends Well, emphasising two key plots: the 'Healing of the King', and the 'Fulfilment of the Tasks'. Both of these occur in story nine of day three of Boccaccio's Decameron, recognised as Shakespeare's primary source for his play. In his Narrative and Dramatic Sources, Bullough reprints William Painter's 1575 translation of Boccaccio, his 'Thirty-Eight Novell' of "The Palace of Pleasure". ${ }^{56}$ The story closely follows that of Shakespeare's play, but as is now to be expected, Shakespeare re-shapes his folk-tale and literary source material, doubling, expanding and even subverting it for his own ends.

There are several examples of departures from Boccaccio, such the addition of the Countess and Parolles characters and Shakespeare's doubling of the ring plot - just as in The Merchant of Venice - which considerably complicates both Helena's test of the impossible tasks and her infamous bed-trick. Not only does Helena have her proxy gain Bertram's family ring to fulfil one of the impossible tasks set for her, Diana also gives Bertram a ring in exchange. This becomes problematic when Bertram later tries to present his ring to his new fiancée and the King recognises it as his own, gifted to Helena. In turn, this plants suspicions in the King's mind that Bertram may have had a hand in Helena's unexpected death. The expansion of the testing and the muddying of the identification by rings motif is representative of what Shakespeare continues to do with his folk-tale sources and the tensions inherent in his play.

Lawrence, among others, ${ }^{57}$ also suggests the French story of Le Livre du Très Chevalereux Comte d'Artois et de sa Femme as an analogue for All's Well. Lawrence uses

\footnotetext{
${ }^{54}$ Davis and Richards 63.

${ }^{55}$ See Drakakis 40.

${ }^{56}$ Geoffrey Bullough, ed. Narrative and Dramatic Sources of Shakespeare, Volume II: The Comedies 1597-1603 (London: Routledge and Kegan Paul, 1958).

${ }^{57}$ See Cole 47.
} 
this text in a similar way to Brunvand in relation to Tale Type 901 and The Taming of the Shrew: to show that All's Well That Ends Well's test of the impossible tasks is firmly rooted in folklore. In this tale, the Count d'Artois and his wife are childless. Because of his sadness at this situation, the Count leaves home until his wife can accomplish three tasks including falling pregnant with his child. To achieve the pregnancy the Countess arranges a bed-trick, a device which has its own long storytelling tradition. Leggatt notes that it occurs in the Bible and in classical mythology, ${ }^{58}$ and cites Marliss Desens who has recorded 44 plays that make use of this plot in Shakespeare's time. ${ }^{59}$ In this we can see Shakespeare's magpie-like collection from a range of folk-tale motifs.

Another important folk tradition that All's Well is connected to is the story of Patient Griselda (ATU Tale Type 887), and of whom Boccaccio also writes in the Decameron. Both Leggatt and Robert Y. Turner ${ }^{60}$ comment on the use of this folk-tale and link it to a trend during Shakespeare's lifetime of 'Prodigal Son' plays. These stories focus on well-born young men who reject their wives to live hedonistically. Eventually their wickedness catches up with them; they learn the error of their ways, the value of their wives, and return to them. Turner argues that Shakespeare adapts Boccaccio to emphasise this kind of journey in Bertram, ${ }^{61}$ but I agree with Leggatt who sees the Prodigal Son plays not as analogues to All's Well but rather as drawing on a "stockpile of popular conventions that the anonymous writers used one way and Shakespeare used another." ${ }^{62}$ Thus I contend that Shakespeare's plays grow organically from folk-tale and literary sources that he amalgamates, re-shapes and even subverts.

In assessing Shakespeare's exposure to folklore, the extent to which Elizabethan England was an oral culture is underestimated. David Cressy's work on calculating adult literacy in early modern England has been debated but generally upheld. ${ }^{63}$ Based on the use

\footnotetext{
58 Russell Fraser, All's Well That Ends Well (Cambridge: Cambridge University Press, 2003). Introduction by Alexander Leggatt 2.

${ }^{59}$ See Wendy Doniger, The Bedtrick: Tales of Sex and Masquerade (Chicago: University of Chicago Press, 2000); Fraser 3.

${ }^{60}$ Robert Y. Turner, "Dramatic Conventions in All's Well That Ends Well", Modern Language Association 75.5 (1960).

${ }^{61}$ Turner 501.

62 Leggatt in Fraser 5.

${ }^{63}$ Generally speaking Cressy's postulated literacy rates have been regarded as a minimum on the basis that, as Margaret Spufford and Keith Thomas argue, more people probably knew how to read than how to write their
} 
of signatures on court records, he has argued for a literacy rate of around $30 \%$ for men and $10 \%$ for women. ${ }^{64}$ Cressy also maintained that there were higher literacy rates in London than in rural areas. This is persuasive as London was the centre of business and government, as well as the book trade. Literacy rates were certainly increasing during this period as there were calls for its spread in order to inculcate godliness. This increase was promulgated by Protestantism, as well as a general improvement of educational opportunities. But overall who was lettered and who was not was slow to change. ${ }^{65}$

The invention of printing and the subsequent increase of printed texts should not be seen, however, as some kind of death knell for oral culture. Indeed, Adam Fox and Daniel Woolf write convincingly of the "overlapping spheres of the oral and the literate". ${ }^{66}$ Likewise, Alexandra Walsham argues that "cultural traffic did not travel in a single direction": that print had an effect on oral tales and vice versa. ${ }^{67}$ Walsham calls this effect "dissemination." ${ }^{68}$ For example, a folk-tale might be sparked by a written medieval romance, then circulate orally, before being committed again to paper. Arthurian legend and its relationship with Thomas Mallory's Morte d'Arthur is one such example. Similarly, ballads provide a further case study where "a ballad might be encountered sung by a voice, as a printed broadside, as a transcript of a performance or a printed text ... as part of a miscellany, or in print or manuscript pasted on the wall of an alehouse or tavern." ${ }^{69}$

Shakespeare's rural background would have resulted in him having a reduced access to books, which were regarded as luxury items, ${ }^{70}$ as well as fewer literate adults with whom to come into contact. In a village lettered men, for example the scrivener or town-crier, had

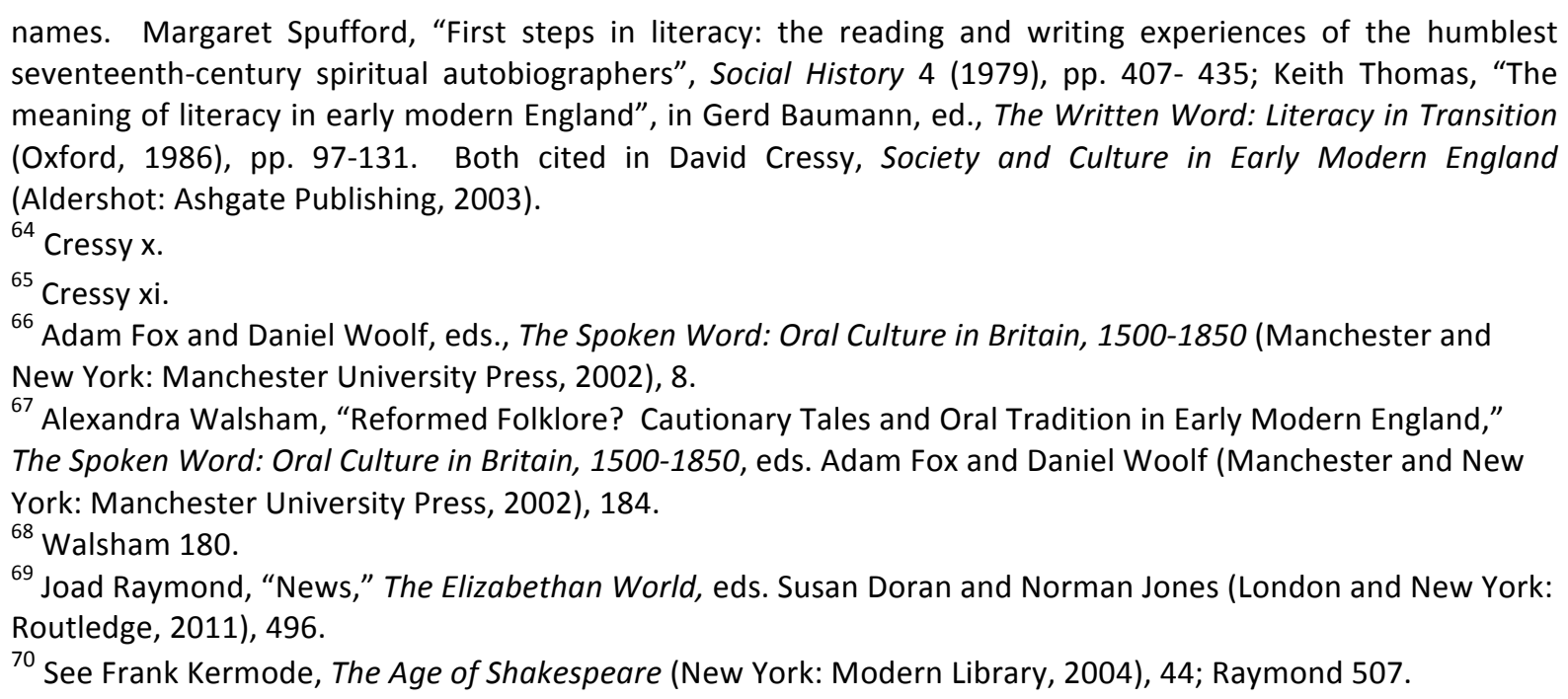
seventeenth-century spiritual autobiographers", Social History 4 (1979), pp. 407- 435; Keith Thomas, "The meaning of literacy in early modern England", in Gerd Baumann, ed., The Written Word: Literacy in Transition (Oxford, 1986), pp. 97-131. Both cited in David Cressy, Society and Culture in Early Modern England (Aldershot: Ashgate Publishing, 2003).

${ }^{64}$ Cressy $x$.

${ }^{65}$ Cressy xi.

${ }^{66}$ Adam Fox and Daniel Woolf, eds., The Spoken Word: Oral Culture in Britain, 1500-1850 (Manchester and New York: Manchester University Press, 2002), 8.

${ }^{67}$ Alexandra Walsham, "Reformed Folklore? Cautionary Tales and Oral Tradition in Early Modern England," The Spoken Word: Oral Culture in Britain, 1500-1850, eds. Adam Fox and Daniel Woolf (Manchester and New York: Manchester University Press, 2002), 184.

${ }^{68}$ Walsham 180.

69 Joad Raymond, "News," The Elizabethan World, eds. Susan Doran and Norman Jones (London and New York: Routledge, 2011), 496.

${ }^{70}$ See Frank Kermode, The Age of Shakespeare (New York: Modern Library, 2004), 44; Raymond 507. 
a public literacy role. They transmitted news from an oral to a written medium or vice versa. This idea of a group literacy is also illustrated by the above ballad example: those who could read the printed ballad would gather with those who could not and share the text. The sharing of stories, oral and written, is important, occurring from the pulpit, around the fire, at the tavern. Shakespeare grew up in this kind of disseminated oral tradition. In writing about what Shakespeare read, Robert S. Miola defines his topic narrowly, focusing overwhelmingly on written texts and revealing the understandable bias scholars have towards physical documents. Even when discussing Shakespeare's reading of "traditions" stock plots, for example, as opposed to specific plays or novellas - Miola concentrates solely on those from written sources. ${ }^{71}$ While he does acknowledge other "echoes" as being possible influences for Shakespeare's work, he doesn't take into account non-literary sources. Thus Fox and Woolf's view of "overlapping", or Walsham's "dissemination" effect, whereby the written and spoken word feed into and out of one another, is ignored in a way which is typical of the underestimation of the significance of oral culture. To me this is a major omission. However, Miola does conclude, as I do, that Shakespeare "reshapes" the material he uses, "conjoin[ing] separate texts and traditions freely and unpredictably."72

It is therefore reasonable to argue that Shakespeare encountered folk-tales as a key aspect of popular culture and moulded the plots of his plays from them. This is particularly so when folk-tale motifs such as the tasks imposed can be shown to have had widespread circulation throughout Europe in a variety of tales, such as the 'Taming of the Shrew'. In fact the overlapping relationship between the printed and spoken word provides a compelling image of Shakespeare's use of source materials. Literature and folk-tale bleed together, just as they do in his plays. Shakespeare's use of a variety of sources in turn plays a role in dissemination by combining written and oral sources and producing them reshaped in both an oral dramatic form, and a written script form. In turn this drives ways of making the familiar stories unfamiliar. ${ }^{73}$

\footnotetext{
${ }^{71}$ Robert S. Miola, Shakespeare's Reading (Oxford: Oxford University Press, 2000), 14.

72 Miola 154.

${ }^{73}$ See Alexander Leggatt, ed., The Cambridge Companion to Shakespearean Comedy (Cambridge: Cambridge University Press, 2002), xiv.
} 
Shakespeare's employment of a range of sources is in keeping with the goals of Renaissance writers generally. While Ben Jonson criticised Pericles for being "mouldy", ${ }^{74}$ the aim of good writing was to imitate; being artificial was praise-worthy. The principle was to draw on classical sources, selecting details and writing in such a way as to come as close to the original as possible. This was a method championed by the Elizabethan grammar school curriculum, thus experienced by Shakespeare. In employing recurrent motifs or plots, like that of the imposed test, these, as mentioned above, became "encrusted with meanings", which Shakespeare could shape for his own purposes. ${ }^{75}$ There are examples of tests in classical sources, the Bible and Romance. In classical myths and legends, such as the twelve labours of Hercules, which is alluded to in all three plays, tasks are imposed that are intended to be impossible. ${ }^{76}$ While these are different to those used in Shakespeare, for example in that Hercules' labours are intended as punishment for his murder of his family, we see that tasks are accomplished through the hero or heroine's own cleverness, or the intervention of a helper, even when this is contrary to the intentions of the tester. One "encrusted meaning" then, is that there is always a way to fulfil the theoretically impossible task.

In the Bible, God tests the integrity of various people such as Adam and Eve, and Job. Adam and Eve are forbidden to eat the fruit of the tree of knowledge; their obedience is tested. God permits Satan to test Job's righteousness. ${ }^{77}$ There are rewards and punishments given as a result of the tests' success or failure: Adam and Eve are expelled from the Garden of Eden, but Job is rewarded with a new family and more wealth. Therefore there is a clear moral lesson associated with tests and their consequences. The idea of tasks operating as a moral litmus test can also be seen in Romance, where the worthy always triumphs, such as the Arthurian story of the 'Sword in the Stone'. ${ }^{78}$ It is Arthur who is destined to be the King of England and therefore he is the only person who can pull the sword from the stone.

\footnotetext{
${ }^{74}$ Quoted in Scragg, Mouldy Tales 1.

${ }^{75}$ Scragg, Alternative Tales 2. Also: "genius lay not in the invention but in the transformation," Miola 2.

${ }^{76}$ Other examples might be 'Jason and the Golden Fleece', and 'Cupid and Psyche'.

${ }^{77}$ Another example is Abraham whose faith is tested by his willingness to sacrifice his son Isaac.

${ }^{78}$ Further examples might be 'Sir Gawain and the Green Knight', and the 'Quest for the Holy Grail'.
} 
Hence the audience expectation of a testing cycle is that those who are worthy will pass, regardless of how impossible the tasks seem when imposed. Furthermore, the test motif espouses a moral imperative; the test has become inextricably linked with virtue. Because these meanings are familiar, as Scragg argues, audience expectation can be "harnessed"; ${ }^{79}$ Shakespeare can choose to meet or subvert the expectations an audience has when witnessing a character being tested. And this choice allows for the re-shaping of folk-tale motifs as well as indicating the movement of the play as a whole.

A further reason why audiences expect that the worthy will pass their assigned test and therefore demonstrate prowess is because we anticipate a moral at the close of a tale; stories are considered to have an educative function. ${ }^{80}$ This dovetails with the general expectations of both theatre and the genre of comedy. In the Renaissance, as to some degree now, the theatre was held to be a place where "social customs were learned and social behaviour was modelled" ${ }^{81}$ Comedy too has this social role. François Laroque calls this expectation "corrective comedy": 82 laughing at someone in order to persuade them to address their shortcomings. Jonson too saw the purpose of the genre as being one of "social correction" 83 and although Shakespeare took a different approach, in choosing to write comedies he does draw on these traditions of the genre. The Greek New Comedy of Plautus and Terence emphasised social reconciliation and renewal: the reassertion of traditional values at the play's conclusion. ${ }^{84}$ This is a further confluence: just as folk-tales, theatre and comedy have educative purposes, they also have a strong conservative element. Coming from a rural background, it is likely that Shakespeare too held these conservative beliefs $^{85}$ so the virtues his comedies promote are those which uphold traditional morals to promote a harmonious society, which is in keeping with the expectation that the worthy will pass their assigned tests.

\footnotetext{
${ }^{79}$ Scragg, Mouldy Tales 8.

${ }^{80}$ See Scragg, Alternative Tales 1.

${ }^{81}$ Arthur F. Kinney, ed., The Oxford Handbook of Shakespeare (Oxford: Oxford University Press, 2012 ), 7.

${ }^{82}$ François Laroque, "Shakespeare's Festive Comedies," A Companion to Shakespeare's Works, Volume III: The Comedies, eds. Richard Dutton and Jean E. Howard (Malden: Blackwell Publishing, 2003), 38.

${ }^{83}$ See Ralph Berry, Shakespeare's Comedies: Explorations in Form (New Jersey: Princeton University Press, 1972), 17.

${ }^{84}$ See Frye 94.

${ }^{85}$ See Jonathan Bate, Soul of the Age: The Life, Mind and World of William Shakespeare (London: Penguin Books, 2009), 73.
} 
Wedding and Bedding: Marriage and Testing

A harmonious society is represented in Shakespeare's plays, as in comedies generally, by the traditional institution of marriage. It is commonplace to observe that Shakespeare's comedies close with weddings, often even in multiples. In depicting marriages The Taming of the Shrew, The Merchant of Venice and All's Well That Ends Well are no different. However, what is striking about these three plays is where the marriages occur. Unlike Shakespeare's other comedies, the placement of the weddings in the middle of the drama sets these plays apart. ${ }^{86}$ In The Shrew, Petruccio and Katherina's shambolic wedding occurs almost precisely at the mid-point of the play, which in the most recent Arden edition is Act 3, Scene 2. The marriage between Portia and Bassanio occurs at the same point in The Merchant of Venice. In All's Well, Helena and Bertram's wedding occurs even earlier: Act 2, Scene 3 in the Arden edition. Due to this unusual placement, it is clear that these plays are less focussed on the journey from wooing to wedding. The nuptials may occur at the centre of the drama, but in all three cases the consummation of the marriages is delayed.

Unlike other Shakespearean comedies, the challenge is not getting individuals to the altar, but to the bedroom. In The Taming of the Shrew Petruccio believes he first needs to tame his wife. For the couple in The Merchant, the realities of the prior pound of flesh bond interrupt the ceremony. And in All's Well That Ends Well, it is the groom's own resistance to his marriage that causes him to flee and leave the impossible tasks in his wake. These events cause a disruption to the expected course of the rite; there is a gap between the vows and the physical union of the marriage. What then comes to fill the space is the testing cycles of the plays. The successful completion of the tests is required before the marriages can be made whole. Therefore, the test motif has a structuring effect: falling between the weddings and the consummation of the marriages it shapes the plot of the plays by generating conflict to resolve.

However, the tests have more than just a structural function. They also have a thematic role. Because the physical union between husband and wife is contingent upon the accomplishment of the imposed tasks, and because these tasks have a moral

\footnotetext{
${ }^{86}$ Cymbeline, which also follows a kind of testing structure, is also an exception as the marriage between Innogen and Posthumus has occurred just before the start of the play.
} 
component, they embody virtue. As the tested characters work their way through their labours, both private and public concerns are revealed. The anxieties in the plays are primarily around controlling female sexuality. In her tests Katherina is called on to demonstrate her ability to control her tongue, which symbolises chastity. The ring plot of The Merchant hinges on the wedding ring as a signifier of faithfulness. Helena proves her commitment to her marriage by fulfilling Bertram's tasks, but to do so she employs the questionable bed-trick. The virtue the 'testee' needs to demonstrate by accomplishing their tasks is fidelity.

We see then, that tests have an educative function: emphasising fidelity. This must be achieved before the marriage is consummated in the bedroom. I take Leggatt's insight that "the folk-tale task is a symbolic way of achieving the personal adjustment that reality requires" one step further. In these three plays, the test motif becomes a way of demonstrating the transformation that a marriage requires. Just because Katherina and Petruccio, Portia and Bassanio, or Helena and Bertram are married by the middle of their plays does not truly make them husband and wife, as the final step of the marriage ceremony, the sexual consummation, is yet to be fulfilled. This is contingent upon the passing of the tests to ensure fidelity, through which process both the testee and the tester must make adjustments. In keeping with folk tradition, transformation is required. Once this is achieved, physical union follows, and the individuals become a couple. However, we must avoid suggesting that Shakespeare simply presents the expected folk-tale lesson such as 'Wives be faithful to your husbands'. As Shakespeare expands his folk-tale sources, he complicates his themes. Ideas are presented contrapuntally, ${ }^{87}$ juxtaposing different views on fidelity and marriage. This can set romance alongside reality when ideals clash with the real world.

The idea of marriage as union and its associated tensions comes directly from the historical context of the early modern period. Lawrence Stone described the five steps to a sixteenth-century marriage: firstly a legal contract between parents; then an oral promise between the spouses; then three readings of the banns. The church wedding could then proceed, and sexual consummation would seal the bond. ${ }^{88}$ The implication that the

\footnotetext{
${ }^{87}$ See Marjorie Garber, Shakespeare After All (New York: Pantheon Books, 2004), 7.

${ }^{88}$ Lawrence Stone, The Family, Sex and Marriage in England, 1500-1800 (New York: Harper and Row, 1977).
} 
consummation is crucial to forging a marriage is confirmed by Martin Ingram who observes that if couples who were betrothed had sexual intercourse "their union became immediately and irrevocably binding." 89 These steps may define the act of marriage, but not what kind of marriage then ensues. There were two competing ideals in Elizabethan times: the hierarchical marriage and the companionate marriage. Both views were firmly held and championed, but were mutually exclusive.

The hierarchical marriage was based on the model of the commonwealth in microcosm, where the husband has authority over his wife, children and servants just as a prince does over his subjects. This in turn reflects the dominion God has: "royal and patriarchal authority were ... natural manifestations of a divinely ordered hierarchy." ${ }^{90}$ In opposition to this highly ordered view is that of the companionate marriage. Increasingly in the Renaissance period the "existence of love and mutual attraction" ${ }^{91}$ were regarded as a necessary foundation of marriage. This is clearly seen by the additional reason for marriage added into the Book of Common Prayer by Archbishop Cranmer in 1549 of "mutual society, help and comfort, that the one ought to have of the other, both in prosperity and in adversity". ${ }^{92}$

These two ideals are completely contradictory. As Stone accurately summarises, "the increasing stress laid by the early seventeenth-century preachers on the need for companionship in marriage ... tended to undercut their own arguments in favour of the maintenance of strict wifely subjection and obedience." ${ }^{\prime 3}$ । would argue that the tension between the hierarchical marriage and the companionate marriage relates to the wife's position: whether she is elevated to the status of a companion, or held to be lower in status than her husband. Tim Stretton places this tension firstly within a broad context of negative

Web. 25 July 2012. <http://hdl.handle.net/2027/heb.01414>.

${ }^{89}$ Martin Ingram, Church Courts, Sex and Marriage in England, 1570-1640 (Cambridge: Cambridge University Press, 1987), 190.

${ }^{90}$ Ingram 126.

${ }^{91}$ See David Cressy, Birth, Marriage, and Death: Ritual, Religion and the Life-Cycle in Tudor and Stuart England (Oxford: Oxford University Press, 1999), 261; Diana O'Hara, Courtship and Constraint: Rethinking the Making of Marriage in Tudor England (Manchester: Manchester University Press, 2000), 6.

${ }^{92}$ Quoted in Stone 136.

${ }^{93}$ Stone 325. 
attitudes towards Elizabethan women, and then within contemporary concerns about status, position and order. ${ }^{94}$

Shakespeare himself is a good example of the kind of person creating consternation for the nobility in this period. Stretton points to changing economic climates generating wealth for merchants and yeomen, thus allowing them to earn sufficient money to become gentlemen. Conversely this could be seen to disrupt a biblically determined social order. The religious upheavals of the period also played into fears about order, and lead to "statesanctioned calls for obedience," ${ }^{95}$ such as homilies on the subject to be delivered in parish churches. As noted, such sweeping concerns about status and order were also reflected in anxieties about the position of women. Lynda E. Boose, like Stretton, points to a rise in women being specifically accused of crimes such as fornication and adultery. ${ }^{96}$ Texts such as the ballads and pamphlets which provide background to The Taming of the Shrew "presented positive and negative female stereotypes, railing against disorderly women and praising the chaste and the modest." ${ }^{\prime 97}$ However just as we will see that the tester becomes the testee when a task is imposed, the vitriol against the disorderly woman rebounds on the man who is charged with keeping her under control. ${ }^{98}$ The slur 'cuckold' is used for this purpose. If a husband is not doing his duty in controlling his wife, this implies that she is of lower status and requires control. Ultimately, while a companionate marriage may well have been an ideal, there was clearly strong conflict with the competing hierarchical view of wifely submission to her husband. ${ }^{99}$ Shakespeare examines the ideas of the companionate and hierarchical marriage contrapuntally in his plays by using folk-tale devices such as the test which he inverts. In doing so he develops beyond a straightforward moral lesson and moves towards metamorphosis and subversion.

While critics have acknowledged the inclusion of folk-tale sources in Shakespeare's plays, this acknowledgement has become a way to excuse the perceived problems

\footnotetext{
94 Tim Stretton, "Women," The Elizabethan World, eds. Susan Doran and Norman Jones (London and New York: Routledge, 2011), 338.

${ }^{95}$ Stretton 339.

${ }^{96}$ See Lynda E. Boose, "Scolding Brides and Bridling Scolds: Taming the Woman's Unruly Member," Shakespeare Quarterly 42 (1991). Web. 8 March 2012. <http://www.jstor.org/stable/2870547>, 184; Stretton 339.

${ }^{97}$ Stretton 339.

${ }^{98}$ See Stretton 340.

99 See Ingram 143; Stone 325.
} 
generated by his texts; that because romance elements are incorporated into realistic settings, or because psychological realism does not seem to sit comfortably alongside romance plots, his dramaturgy is flawed. However I would argue that there is a need to analyse the folk-tale elements in Shakespeare's plays in a way that doesn't seek to tidy them away or absolve Shakespeare for re-shaping folk-tale rather than literary sources, and to make this case I use the motif of the test to prove worthiness. In all three comedies the completion of the imposed tasks demonstrates the transformation that a marriage requires. The motif has both a structural and thematic function: as the tasks fall in the centre of the plays, they are the source of conflict that must be resolved, and their nature reveals private and public anxieties. While all the couples in the three texts do achieve some unity, which fits with audience expectations, each play also concludes with ambiguity. This reflects the tension that a testing process generates. As with any test, a power imbalance ensues: someone is the tester, setting the tasks and judging the outcome; and someone is the testee, who attempts the completion of the tasks. The process of testing is disturbing and painful and although an accord is reached, the uncertain conclusions suggest that the testing will need to be ongoing; just because an equilibrium is found does not make it permanent nor stable. Thus, the test motif is an excellent representation of what Shakespeare does with his folk-tale sources: he doubles, expands, subverts. This allows genuine richness and depth to be added to his plays: characterisations to be developed, genres to be explored, and ideas to be contrapuntally presented for consideration. 


\section{Chapter Two}

\section{The Shrew who turned into a Wife: The Taming of the Shrew}

Brunvand argues convincingly that The Taming of the Shrew "is probably closer to being a pure dramatized folktale than ... any other of Shakespeare's plays."100 The folk elements within the play include the figure of the shrewish wife; the carnivalesque, topsyturvy atmosphere where a drunk could transform into a lord and a shrew could transform into an obedient wife; the absurd statements Katherina must echo; and the wager of the three wives. These last two elements are examples of the test to prove worthiness, which Shakespeare expands considerably in his play, far beyond that of the testing cycle apparent in the anonymous The Taming of a Shrew. In doing so, we see Ovid's sentiment that "everything changes, nothing is lost" at work: Shakespeare includes folk-tale sources, but manipulates them to raise questions about the adjustments marriage requires, and about the nature of marriage itself.

The background which leads up to the first key test to prove worthiness, the absurd statements in Act 4, Scene 5, is one which shows Petruccio overruling his new wife's desires. Straight after their chaotic wedding Petruccio states his intention to leave immediately, whereas Katherina wishes to stay for the feast. Ignoring her conditionally expressed request that "if you love me, stay" (3.2.205), Petruccio pretends they are beset by thieves and exits. Katherina's statement is an example of a broad range of conditionals in the play - that something is contingent upon something else - and shows the manipulative potential of these conditionals. Later, at his country house in Verona, Petruccio outlines in a soliloquy his intended strategies for taming his bride, including preventing her from eating or sleeping, as "This is a way to kill a wife with kindness, / And thus I'll curb her mad and headstrong humour" (4.1.197-8). This leads into a feigned conflict with the Haberdasher and Tailor over new outfits for Katherina as an example of the methods Petruccio plans to employ. Even though the attire is rejected, Petruccio intends visiting Baptista and muses aloud on the time the couple are likely to arrive. Katherina disagrees with his estimations

${ }^{100}$ Brunvand, Comparative Study 176. 
and consequently Petruccio refuses to leave, warning her: "I will not go today, and ere I do, / It shall be what o'clock I say it is" (4.3.193-4).

Petruccio therefore establishes a pattern whereby Katherina is denied what she desires, but may gain compensation on the proviso that she agrees with her husband. In turn this makes the testing structure clear: if Katherina fails to agree she is punished, but if she concedes she is rewarded. This is precisely what is at stake during the first key task of the absurd statements. Once Katherina and Petruccio are finally making their way to Baptista's house, Petruccio observes "how bright and goodly shines the moon!" (4.5.2) As it is during the day, Katherina naturally corrects his comment: "it is the sun that shines so bright" (5). Petruccio explicitly states the terms of the task to his wife: "It shall be moon or star or what I list / Or e'er I journey to your father's house." (4.5.7-8) Hortensio, who has been staying with the couple to learn Petruccio's taming methodologies, urges Katherina to concur with her husband: "Say as he says, or we shall never go" (11). Katherina capitulates:

Forward, I pray, since we have come so far, And be it moon or sun or what you please, And if you please to call it a rush-candle, Henceforth I vow it shall be so for me. (4.5.12-15)

Petruccio probes this supposed new-found obedience by repeating his observation about the moon, which Katherina echoes. He then reverses his position and states the moon is the sun, which she likewise repeats. Hortensio, judge-like, declares Katherina has passed her test: "Petruccio, go thy ways, the field is won" (24). However the testing sequence isn't yet complete. Vincentio enters also en route to Padua. Petruccio asks his wife "Hast thou beheld a fresher gentlewoman?" (30). Katherina concurs this new person is a "Young budding virgin" (38). Petruccio then corrects her: "I hope thou art not mad. / This is a man" (43-4), at which Katherina excuses herself. Now that Katherina speaks in accordance with her husband's absurd statements, the party continues their travel. It is Hortensio who utters the final lines of the scene, highlighting both the battle that Petruccio has won, and the lesson Hortensio can learn from it: "Well, Petruccio, this has put me in heart. / Have to my widow, and if she be froward, / Then hast thou taught Hortensio to be untoward" 
(4.5.78-80). Petruccio is declared the winner of this round; he has apparently succeeded in teaching not only his wife to agree with him, but also Hortensio how to deal with unruly women.

Regardless of Hortensio's triumphant statement, Petruccio is not sufficiently secure in his wife's obedience to be done with testing her. The additional tests are a development from Shakespeare's sources and suggest that a straightforward moral lesson may be difficult to draw. Once the couple have arrived in Padua, the plot regarding the assumed and mistaken identities of Tranio and his master Lucentio is unravelled. Katherina wishes to watch the outcome of the debacle. Petruccio agrees that they can, but first insists on another conditional task: Katherina must kiss Petruccio. Katherina objects to kissing in public, so Petruccio threatens as previously: "Why then, let's home again" (5.1.138). At this warning, Katherina surrenders: "I will give thee a kiss. Now pray thee love, stay." Petruccio is pleased at her response: "Is this not well? Come, my sweet Kate" (139-40). Here Petruccio follows the identical testing structure, including the same punishment. He does, however, shift the test from a verbal agreement to a physical action: Katherina making a public display of affection. Rather than just echoing Petruccio's statements, Katherina must now overcome her embarrassment (see 5.1.137) to kiss her husband in the middle of a street. Her obedience must override her modesty.

The final task imposed on Katherina is the wager which occurs at Bianca and Lucentio's wedding feast. Hortensio is also present with his new wife, the Widow. She and Katherina start arguing, to the great amusement of the men. In jest, Petruccio bets on the outcome of the spat, "A hundred marks my Kate does put her down" (5.2.36), which foreshadows the coming wager. Once the three women exit, the men continue their talk of hunting and gaming. Baptista issues a challenge: "I think thou [Petruccio] hast the veriest shrew of all" (65), to which Petruccio responds by proposing the formal wager:

Let's each one send unto his wife, And he whose wife is most obedient To come at first when he doth send for her Shall win the wager which we will propose. (5.2.67-70) 
Lucentio goes first and sends his servant to "bid your mistress come to me" (78-9). Bianca replies that she is otherwise occupied and cannot come as requested. Hortensio goes next, sending a servant to "entreat my wife to come to me forthwith" (90-1). However the Widow counters that she prefers that if her husband needs her, he should come to her. Petruccio is the final husband, and sends his servant to "command her come to me" (100). I find the change in verbs, from the gentler "bid" and "entreat", to Petruccio's authoritative "command", telling. It is also interesting that the choice of verbs here is not pointed directly at the wives. Although the servants are instructed to repeat these imperatives, the additional audience which notes the implied escalation of force is the husbands. The shift in intended audience reflects Shakespeare's subversion of the wager test and its folk-tale tradition. Nevertheless, the folk-tale nature of the trebling, whereby the third request or object is invariably the successful one, as in The Merchant of Venice's three caskets, means that we are hardly surprised when Katherina enters asking "What is your will, sir, that you send for me?" (106) A shocked Baptista declares Petruccio has won the bet. However Petruccio still wishes to demonstrate his dominance over his wife, and says "I will win my wager better yet / And show more sign of her obedience - / Her new-built virtue and obedience" (122-4). Consequently Katherina has further tasks to complete, starting with removing her hat and throwing it to the ground. This suggests both that Petruccio is never entirely certain of his wife's submissiveness, and also that Katherina is not the only subject of these tasks. They can be read as a staged performance for the benefit of the family present and thus as evidence of the re-shaping of folk-tale. Katherina's infamous speech is also at Petruccio's insistence: "I charge thee tell these headstrong women / What duty they do owe their lords and husbands" (136-7). At the end of her homily, Katherina must kiss her husband in public again (see 186). Triumphantly, Petruccio exits with these as his final words:

Come Kate, we'll to bed.

We three are married, but you two are sped.

- 'Twas I won the wager, though you hit the white, And being a winner, God give you good night. (5.2.190-3) 
Petruccio now appears convinced that his methods have tamed his bride and the couple depart. On the surface, Katherina has learnt a simple lesson: be obedient to your husband (note the repetition of the noun in the quotations above), and is rewarded for this by Petruccio publically insinuating that their previously delayed consummation will be delayed no longer. Husband and wife will finally cement their union.

Structurally, the first half of The Taming of the Shrew is primarily concerned with the courtship and marriage of Katherina and her sister Bianca. Of course the latter is conditional on the former; Bianca is not allowed to marry before her elder sibling, much to the chagrin of her sister and Bianca's numerous would-be husbands. Although finding a spouse for Katherina is framed as challenging, Petruccio's convenient arrival in Padua solves the problem swiftly. Therefore the wooing of Bianca by multiple suitors can continue apace. This too is fairly quickly settled in the first half of the play by the one-upmanship gamble between Gremio and Tranio over Bianca's dowry, in spite of the suitors in disguise as tutors. Although there is still the business of unravelling the deceptions that have led to Lucentio and Bianca's marriage, the two courtships are now resolved. This, however, takes us only to the middle of the play. While the disentangling of the various identities does add to the drama of the second half, the primary impetus really lies in the Katherina-Petruccio plot, regardless of their marital status. While the two are wedded by Act 3, Scene 2, they are not yet bedded, as Petruccio chooses to delay the act until he has implemented his taming strategies. Therefore, it is the imposed tasks that drive the story on towards consummation. The development of the folk sources, indicated by the ongoing testing cycle whereby Petruccio continues to probe Katherina's taming to ensure her ability to mould her responses to her husband's wishes, underscores his anxieties about his wife. Thus the test motif serves both a structural and a thematic function.

The testing cycle also indicates that Katherina is presented as the primary subject of the imposed tasks. She must agree with Petruccio's absurd statements; she must kiss when required; she must come when called; she must give a command performance when directed. And when Katherina is tested by Petruccio to perform these tasks, she is actually being tested on her ability to control her tongue in word and in deed. Katherina is, according to Hortensio, "Renowned in Padua for her scolding tongue" (1.2.99). This observation is full of cultural signifiers. Firstly, Katherina's speech is connected to the noise 
she produces both in the amount and in the nature of her words; her "loud alarums" (1.1.126) are to be endured not enjoyed. Her noise also leads to her being labelled a scold and a shrew, presumably in reference to the title. Her inability to be quiet, noise leaking from her, bespeaks an incontinent personality; one lacking in self-control. ${ }^{101}$ "Marked you not how [Katherina] / Began to scold and raise up such a storm / That mortal ears might hardly endure the din?" (1.1.170-2) queries Tranio, drawing together images of Katherina's noise being tempest-like to suggest an immoderate and effusive outpouring that calls for restraint. Being equated primarily with her tongue casts Katherina into a dubious light indeed; controlling her tongue means controlling her very self.

Furthermore, the tongue, as the body's infamous "unruly member,"102 occupied an anxious and ambivalent space in early modern imaginations. We can see this ambiguity at work in the initial fiery interaction between Katherina and Petruccio:

Pet: Who knows not where a wasp does wear his sting?

In his tail.

Kat: In his tongue.

Pet: Whose tongue?

Kat: Yours, if you talk of tails, and so farewell.

Pet: $\quad$ What, with my tongue in your tail? (2.1.214-9)

Petruccio's bawdy jest about his "tongue" being in Katherina's "tail" highlights a connection between the tongue and genitals that underpins much of the unease about the body part. The tongue's seeming independence and curious ability to operate simultaneously both inside and outside the body symbolises the potential destructiveness of the organ, which can influence others even from a distance. ${ }^{103}$ Misogynistic theologians of the time were able to link these concerns to the Fall of Man, as they held Eve's speech to be the principal source of error when she persuaded Adam to eat of the forbidden fruit. ${ }^{104}$ Thus, through Eve's words to Adam, the tongue introduced sin to the world and is to be regarded as devilish. Not only is Eve's mouth responsible for this, but her body also reproduces sin; her

\footnotetext{
${ }^{101}$ See Gail Kern Paster in Aspinall 9.

${ }^{102}$ Quoted in Boose 204.

${ }^{103}$ See Aspinall 9.

${ }^{104}$ See Aspinall 10; Boose 204.
} 
open mouth is analogous to the open womb through which she gives birth. ${ }^{105}$ Speech and sexuality are thus intimately connected: the talkative woman is held to be lustful, the silent woman to be chaste. ${ }^{106}$ As argued, the noise incontinently leaking from Katherina's body could be understood as a sign of a lack of self-control, not only of her speech, but of her person. Because she is so noisy, she must be lascivious. Chastity was the foremost virtue required of women and should be demonstrated by virginity, faithfulness in marriage, or abstinence in widowhood. Proving faithfulness could be achieved by exhibiting the "peculiarly Renaissance virtue of shamefastness and by avoiding all appearances of immodesty". ${ }^{107}$ The OED defines "shamefastness" as "modesty, sobriety of behaviour, decency, propriety; bashfulness, shyness. Also, a feeling of shame, ashamedness." ${ }^{108}$ Shyness and bashfulness, alongside modesty and sobriety, suggests paucity of speech. When Katherina is remonstrated for her immodest speech, she is simultaneously having aspersions cast on her character in terms of her ability to control her sexuality. Petruccio's task of requiring his wife to kiss him in the street highlights this tension: being proper, modest, chaste, but also displaying a sign of sexual affection using the mouth. Therefore Katherina's tongue becomes the signifier of her sexuality and her fidelity. And the testing cycle imposed on her by her husband reveals this subtext Shakespeare develops from his folk-tale sources: Petruccio's personal and public anxieties about women's fidelity; Katherina's power to make him a cuckold and consequently a laughingstock.

There is an important correlation suggested here. In testing Katherina's ability to control her tongue, Petruccio exposes his anxiety about being seen as a man with an unfaithful wife. As valuable as Brunvand's studies of the folk-tale sources of The Taming of the Shrew are, further examination reveals how Shakespeare uses these sources to explore concerns about marriage. The historical context of the play, and the way the text feeds into wider societal concerns of order, place, and the tension between a hierarchical and companionate marriage, emphasise Petruccio's position. Just as the husbands of the unruly,

\footnotetext{
105 Boose 204.

106 Boose 196.

${ }^{107}$ Carol Thomas Neely, Broken Nuptials in Shakespeare's Plays (New Haven and London: Yale University Press, 1985), 14.

${ }^{108}$ shamefastness, n. OED Online. June 2012. Web. 1 August 2012.

<http://www.oed.com/view/Entry/177415>.
} 
shrewish women who were vilified by ballads ${ }^{109}$ and pamphlets aimed at humiliating them into conformity are the real audience of such material, Petruccio is tested alongside his wife. If a woman is out of control, it is the fault of the man who is charged with controlling her. Therefore, the testing of Katherina's sexuality tests Petruccio's masculinity: is it sufficient to control his wife? The correlation, then, is that the testing of Petruccio's masculinity is contingent upon the testing of Katherina's tongue. If Katherina can learn to control her tongue and prove her faithfulness to her husband, then Petruccio can be assured that her agency is likewise curbed and that his children will be his own.

The ideal of a hierarchical marriage is clearly wrestled with in the play, not only in the content of Katherina's so-called submission speech, still to be discussed, but also in direct relation to Petruccio's new status. Petruccio's need to assert his masculinity takes place in the context of his insecurity in his position as a new patriarch in the wake of his father's death. On his arrival in Padua, Petruccio tells his friend Hortensio that "Antonio my father is deceased, / And I have thrust myself into this maze, / Haply to wive and thrive as best I may" (1.2.53-5). This links the marriage to Katherina not only to his financial fortunes and future comfort, but also to his position as the master of his late father's household. This gives Petruccio additional motivation to assert his masculinity in a firm and public manner. Catherine Richardson argues that Petruccio journeys:

from home as [a] relatively 'untried' master of the house, to adventure and the acquisition of a wife, to home as a married man. And this movement sets his house up as a space for the achievement of maturity, a space of education. ${ }^{110}$

Petruccio, as a new patriarch, must be seen to control his wife's sexuality, not only for the sake of his own reputation and to avoid being labelled a cuckold, but also for the sake of his unborn sons; to guarantee them their inheritance.

When we consider the breadth of testing within the play, also suggested by Richardson above, we can see that Petruccio is indeed put to the test. There is a recurring motif of education in The Taming of the Shrew, of which the testing cycle outlined above is a

\footnotetext{
${ }^{109}$ Such as "A Merry Jest of a Shrewd and Curst Wife Lapped in Morel's Skin, for Her Good Behaviour".

${ }^{110}$ Catherine Richardson, “Domestic Life," The Oxford Handbook of Shakespeare, ed. Arthur F. Kinney (Oxford: Oxford University Press, 2012), 215.
} 
key component. To test someone is to ensure that they have learnt what has been put before them and therefore forms part of an educative process. Generally this process is seen only to be applied to Katherina, ${ }^{111}$ but to me this is an overly narrow interpretation. There are many other examples of characters being tested in the play. The hunting Lord's conditional words to his page to disguise himself as Sly's wife is one: "Tell him from me, as he will win my love, / He bear himself with honourable action" (Ind 1.108-9). In a related way, Bianca's rival suitors band together to encourage Petruccio to take on the Herculean task of wooing Katherina (see 1.2.256-7) by offering him financial recompense: "I promised we would be contributors / And bear his charge of wooing, whatsoe'er" says Hortensio (1.2.213-4). Previously mentioned is the gamble for Bianca's dowry between Gremio and Tranio, where Gremio is "out-vied" and Tranio the successful "young gamester" (2.1.389, 403). Lucentio's initial reason for coming to Padua, a famous university town, ${ }^{112}$ is to seek further education (1.1.8-9). The later posing of Lucentio and Hortensio as tutors for Bianca and her sister also fits into this context, and sites private homes as educational institutions, Baptista's house becoming a kind of academy for young ladies. ${ }^{113}$ This is then echoed in Hortensio changing his teaching garb for pupil status when he accepts defeat in his pursuit of Bianca, and instead travels to the "taming school" in Verona where "Petruccio is the master / That teacheth tricks eleven-and-twenty long / To tame a shrew and charm her chattering tongue" $(4.2 .55,57-9)$. Significantly, these examples all emphasise Shakespeare's development of the motif to lend emotional richness to his characters; we are not to just blindly accept them as folk-tale archetypes. The developed motif also demonstrates the pressure exerted on men to conduct themselves in certain ways; their behaviour is tested.

A great deal rests for Petruccio on the testing of Katherina. If she is able to complete her tasks successfully, his masculinity is proven and his strategies for wooing and taming his wife are upheld. Demonstrating his masculinity has several aspects. Firstly, the lines quoted above, where Bianca's suitors encourage the newcomer to woo Katherina by promising financial gain, give the sense of male camaraderie. But they also put Petruccio's wooing into a public arena; an impossible task that he can't back down from without losing face in front of his peers. Similarly, once Hortensio has arrived at the "taming school" the

\footnotetext{
${ }^{111}$ See Miola quoted in Aspinall 13.

${ }^{112}$ See Ann Thompson, ed., The Taming of the Shrew (Cambridge: Cambridge University Press, 2003), 8.

${ }^{113}$ See Richardson 215.
} 
testing of Katherina is conducted in public. While this undoubtedly has a demeaning effect on her, humiliated not just in front of her new servants but also a close friend of her husband's, it has ramifications for Petruccio. His patriarchal position and social standing is at risk. Hortensio is drawn into the happenings of the household. He is witness to the scene with the Haberdasher and the Tailor. As mentioned, Hortensio joins the couple en route to Padua during the absurd statements task, acting as Katherina's advisor and declaring Petruccio's success, not only in appearing to tame his wife, but also in his pedagogy. Always having a fellow male present puts pressure on Petruccio to continue on the path he has privately and publically determined:

Think you a little din can daunt mine ears?

Have I not in my time heard lions roar?

.... And do you tell me of a woman's tongue,

That gives not half so great a blow to hear

As will a chestnut in a farmer's fire?

Tush, tush, fear boys with bugs. (1.2.198-9, 206-9)

After a public pronouncement of male bravado like this, comparing being alarmed of a mere woman's noise to children being frightened of imaginary beasts, Petruccio must succeed at all costs. To do otherwise would render his actions such as his preposterous conduct at his wedding insensitive at best or abhorrent at worst. If, however, his actions can be confirmed as justifiable by a male audience who have already agreed on Katherina's devilish nature she is a "fiend of hell" (1.1.88) - then he can frame his choice of behaviour as heroic; as a Hercules worthy of the task.

The wager scene at the end of the play brings to a head the tension Petruccio experiences in having championed his masculinity, and reveals how his testing of Katherina rebounds on him. There is money and honour and male pride at stake. The men start by asserting their comradeship by making bawdy comments, jesting over hunting and egging on the arguing women. Petruccio is firmly in the position of having his masculinity tested: has he tamed his wife as he claimed he could? Can the shrew be controlled? Does he, wonder of wonders, now have the most obedient wife? To call his audience sceptical is an understatement. Katherina's own father says "I think thou hast the veriest shrew of all" 
(5.2.65). The competition over which wife will come at her husband's call is really a competition between the men: who is dominant, not only over their wives, but over the other husbands as well. The wager has even higher stakes than at first glance. Winning it will not only bag the victorious husband considerable loot, but also bragging rights; raising their social standing amongst the men because their manhood has been proven. As Frances E. Dolan succinctly summarises, "their bet reveals that it has been Katharine's job all along to make Petruchio a winner, to enable him to 'lord' it not only over her, but over other men." 114

Potentially, both Katherina and Petruccio could adopt for themselves strong respective positions of shrewishness or masculinity, archetypes reinforced by Renaissance popular culture. However, cementing extreme stances will not make for a functional or successful marriage, hierarchical or companionate. Doing so would create a situation of brinkmanship. Hence the testing falls precisely where it does, to suggest that neither extreme position can nor should be maintained; that compromise and adjustment is needed. A simplistic folk-tale lesson is not applicable to real life. Bearing in mind the expectation that the worthy will pass their assigned test, and the convention that Shakespeare does not allow unsuitable characters to marry, ${ }^{115}$ there is reasonable belief that Katherina learning to control her tongue will prove Petruccio's masculinity, and that the consummation - the literal and figurative forming of their union - will occur.

Katherina does indeed learn to control her tongue. She accomplishes her tasks to the overall satisfaction of her husband, as we can see by his previously quoted celebratory words at the end of the play. She agrees with Petruccio's absurd statements, and gets to travel to Padua. She kisses her husband in the street, and gets to follow the commotion trailing Lucentio and Vincentio. And she wins Petruccio the wager by coming when called for. In doing so, she not only secures Petruccio the agreed amount, but also an additional substantial dowry from Baptista who offers "twenty thousand crowns, / Another dowry to another daughter, / For she is changed as she had never been" (5.2.119-21). Baptista's spontaneous generosity emphasises the transformation that Katherina has undergone. Her

\footnotetext{
${ }^{114}$ Dolan 33.

${ }^{115}$ For example Sir Andrew Aguecheek is unsuccessful in his wooing of Olivia in Twelfth Night.
} 
own father regards her now as an entirely new woman. But as we know, Shakespeare does not endorse simple folk-tale lessons, so how stable or permanent is this transformation?

Revelling in his successes, Petruccio adds a last-minute addition to the final task when Katherina is asked to "tell these headstrong women / What duty they do owe their lords and husbands" (5.2.136-7). And she proceeds to do so. At some 43 lines, Katherina gives the longest speech of the play, literally out-speaking every other character. While she has been traduced for her noise throughout the play, in her notorious final speech of socalled submission she is voluble indeed. I agree with critics who have pointed out the disparity between the content of Katherina's speech and the performance of it. ${ }^{116}$ Katherina's speech conservatively upholds the traditional perspective of a hierarchical marriage: "Thy husband is thy lord, thy life, thy keeper, / Thy head, thy sovereign" (5.2.1523), therefore "[women] are bound to serve, love and obey" (170). At the same time, though, she undercuts her message by subverting the "obedience" (159) called for in her sermon, and demanded by her own new husband in his tests, using her voice to dominate the room. This calls into question the extent to which Katherina has undergone a transformation. Recalling Ovid's statement that "everything changes; nothing is lost" - that things can transform from one state into another without losing their essential elements we can conclude that Katherina has learnt the art of compromise. Katherina's noise levels have not suddenly been permanently short-circuited to mute. She can acquiesce to her husband's requests by entering when called, by removing her hat when requested, and by speaking when spoken to. But she can also demonstrate her agency by exerting her will in an appropriate and socially acceptable way: speaking at length on an orthodox topic. She can suppress her argumentative tendencies with regards to the time or a show of affection, but can hold her own ground when she desires. On another level, Katherina's control of her tongue also indicates an ability to control her sexuality and thus remain faithful in her marriage. This is a transformation: that of an individual making adjustments in order to be a member of a functioning couple, and a contrapuntal exploration of ideas.

There are further analyses of Katherina's final speech which support this view of subversion. Some 'revisionist' critics, for example, draw attention to the framing effect of

\footnotetext{
${ }^{116}$ See Lisa Hopkins, The Shakespearean Marriage: Merry Wives and Heavy Husbands (London: Macmillan Press, 1998), 42; Coppélia Kahn quoted in Dolan 32.
} 
the opening Induction scenes. ${ }^{117}$ As we have seen, the hunting Lord's page is called to pose as Christopher Sly's wife. This cross-dressing device calls attention to the convention of the apprentice boy actors performing the female roles of Renaissance plays, and calls into question what constitutes 'femininity'. For example, the page is given the advice to smell an onion if need be to induce the stereotypical tears that are a "woman's gift" (Ind 1.123). Furthermore, Bartholomew's first action as Sly's wife is to disobey: refusing to come to bed (Ind 2.115-7). These two actions reinforce the shrew archetype: a woman flouting her husband's desires, and the manipulative use of crying. Furthermore, the inversion depicted in the Induction scenes (the drunk as a lord, the page as a wife) introduces us to a topsyturvy world and creates distance from the 'main' action of the play and the archetypal characterisations. Katherina and Petruccio are characters who exist in the distanced playwithin-a-play, and perform a "fantasy of male dominance", 118 mocking it as such. Just as Bartholomew plays the role of Sly's compliant wife, Katherina plays the role of Petruccio's conformist wife. I agree with Ralph Berry who argues that Katherina's speech is as hyperbolic as Petruccio's vision of male superiority is in Act 3, Scene 2: "119 "She is my goods, my chattels; she is my house, / My household-stuff, my field, my barn, / My horse, my ox, my ass, my anything" (231-3). This lends weight to the argument that there is an intended difference between the content and the performance of the homily, and that Katherina intentionally subverts her show of submission; she will decide how and when to control her tongue.

Petruccio similarly has his asserted male bravado undercut. Despite his adoption of the role, Petruccio's effectiveness as a teacher of taming is called into question in the last scene of the play. Hortensio, as we have already seen, has chosen to be Petruccio's student but is revealed to be a poor one indeed. Bianca, and notably Hortensio's new wife the Widow, appear to rise as new shrews in the final Act. Bianca's bawdy jests at the beginning of the wager scene - "Am I your bird? I mean to shift my bush" (5.2.47) - echo her sister in Act 2, Scene 1. More significantly, the two women object to Katherina's shows of compliance in the removing of her hat and the delivery of her final speech. Bianca wonders "what a foolish duty call you this?" (5.2.131), and the Widow tries to tell Katherina that

\footnotetext{
${ }^{117}$ See Kahn quoted in Dolan 35.

${ }^{118}$ Kahn in Dolan 35.

${ }^{119}$ Berry 67.
} 
"you're mocking: we will have no telling" (138). From her argumentative behaviour towards Katherina, to her hostility at being told what kind of wife she should be, the Widow's conduct is indicative of either Hortensio's inability to learn what Petruccio has to teach him, or Petruccio's ineffectiveness as a teacher. I concur with Lisa Hopkins who argues that Hortensio's “inability to imitate Petruchio even after he has occupied the privileged position of eye-witness and confidant to him may well suggest that ... The Taming of the Shrew has, pointedly, no didactic import", ${ }^{120}$ and therefore no simple moral lesson.

Even though the testing of Petruccio's masculinity is contingent upon the testing of Katherina's tongue, with all that that implies, both are proven over the course of the play. However her display of submission and his display of masculinity are equally undercut. This strongly suggests that Katherina and Petruccio have indeed experienced a transformation. The two step back from the brink. In feeling the need to put his wife through a series of tasks to test her fidelity to him, Petruccio sets up a power imbalance. As 'chief examiner', he determines the task to be imposed and judges whether it has been passed or failed. In agreeing to attempt the tasks, and then in accomplishing them successfully, Katherina appears to accept this imbalance as the status quo. However through the discrepancy between the content and the performance of her final task, Katherina subverts this and demonstrates her own agency. Petruccio gains face amongst his male peers by winning the wager and appearing to control his wife, but the patently untamed Widow makes us query his true success as an educator. With the transformation of the two characters accomplished, consummation can take place.

This anticipated union is foreshadowed by the symbolism in the absurd statement scene. Dolan argues that images of the sun and moon were used by Elizabethans to represent the ideal relationship between a husband and wife, each having their own kind of power: "the analogy helped to explain how the wife could have authority over her servants and children, yet remain subordinate to her husband." ${ }^{121}$ Furthermore, Jeanne Addison Roberts posits that in the following absurdity, that of Vincentio being a young virgin, "the speakers are transforming a man metaphorically into a woman."122 In doing so Vincentio

\footnotetext{
${ }^{120}$ Hopkins 46.

${ }^{121}$ Dolan 30.

122 Jeanne Addison Roberts, "Horses and Hermaphrodites: Metamorphoses in The Taming of the Shrew, The Taming of the Shrew: Critical Essays, ed. Dana E. Aspinall (New York and London: Routledge, 2002), 66.
} 
becomes hermaphroditic; encapsulating both male and female. Just as the sun and moon emblematically represent husband and wife, so too could the hermaphrodite: as husband and wife become one flesh in the marriage ceremony and in the act of sexual union. The 'one flesh' bond becomes particularly important in The Merchant of Venice, as we shall see in the next chapter. Taking into consideration that the testing cycle of The Taming of the Shrew falls between the marriage of Katherina and Petruccio and their consummation, and that completing the set tasks becomes the method by which the transformation required by marriage can be demonstrated, the symbolism highlighted by Dolan and Roberts is compelling. Furthermore it suggests a historically appropriate compromise between a strictly hierarchical marriage, and a modern audience's preference for a companionate marriage. Katherina has learnt to control her tongue with all that this connotes in terms of her chastity and fidelity, but is not brainwashed into robotically performing the role of the dutiful wife. Her desire to be heard can be self-monitored and used when appropriate. In the spirit of Ovid it has not been eliminated, but changed. Similarly, while Petruccio can rest contented that Katherina's public performance of obedience has secured him the position of 'top dog' and in control of his wife, the way Katherina subverts her performance, and the rise of new shrews, suggests that his masculinity too has evolved.

Thus satisfied that his masculinity has been demonstrated by Katherina during the wager scene, Petruccio beckons to his wife that "we'll to bed" (5.2.190). This signals his intention to consummate their union, the final act in completing the marriage rite. This provides further evidence that the required transformation of both Katherina and Petruccio has been made. As discussed above, Katherina has learnt to control her tongue. This is symbolic of her self-control in terms of both her language and her body. Petruccio, at this stage, has no grounds for concern that her previous immodesty in speech will equate in future to any sexual immodesty. Thus reassured, he can drop his taming-scholar guise and embrace his status as mature patriarch of a new branch of his family. The two can become one.

As Petruccio and Katherina exit to their bed, Hortensio says "Now go thy ways; thou hast tamed a curst shrew," and Lucentio comments: "Tis a wonder, by your leave, she will be tamed so" (5.2.194-5). Hodgdon's glosses of Hortensio's choice of pronouns of "thy" and "thou" indicate that these do not necessarily refer specifically to Petruccio, but could also 
equally refer to Katherina. ${ }^{123}$ The ambiguity of the pronouns opens up a space into which can be read that together the spouses have learnt compromise and come to an accord. Furthermore, the tone of Lucentio's final line is one of dubiousness, particularly of the likely permanency of Katherina's taming, or perhaps of the methods used to achieve this. Taken together, the two characters' words reveal ambivalence. They raise questions about whether Katherina has indeed been tamed and, if so, whether this is a lasting transformation. Setting aside the issue of Katherina's taming, which I have argued has been a self-determined choice in order to be a member of a married couple and required to be demonstrated for the sake of Petruccio's masculinity, we can focus rather on the stability of the metamorphoses. Just as Bianca and the Widow's comments reveal a need for an equivalent testing cycle in their relationships in order to produce coupledom, Hortensio and Lucentio's wonder hints at the need for ongoing testing in Katherina and Petruccio's marriage - there is no straightforward 'happily ever after' here. Can we ever be sure that a lesson has stuck?

It is clear that at the end of the play Katherina and Petruccio have found some harmony, and that this is shown by the intended consummation of their marriage in the unwritten next scene. In order to get to this point both individuals have been subjected to tasks which have questioned what they hold dear. Katherina's tongue has been vilified and she has therefore learnt to control her speech, emblematic of her fidelity. Petruccio has bombastically painted himself as 'the big man on campus' and has managed to both secure this position and to have it re-framed without losing face, to prove his masculinity. A balance has been found that has allowed the two to keep agency and still make the compromising transformations required by marriage. Whether this equilibrium can be maintained is less certain; testing is an ongoing process because we can never really be completely secure in our partner's fidelity. Thus in The Taming of the Shrew, Shakespeare subtly subverts the folk-tale test motif by having tasks rebound on Petruccio: the testing of Katherina simultaneously tests him. This allows ideas about the nature of a hierarchical marriage and companionate marriage to be examined contrapuntally. Furthermore, by developing the context of the tests, Shakespeare uses the folk-tale motif to add a level of psychological realism to his characterisations.

${ }^{123}$ See Hodgson 305. 


\section{Chapter Three}

\section{The Princess and the Ring: The Merchant of Venice}

On many levels, testing is central to Shakespeare's The Merchant of Venice. As the play is deeply concerned with bonds, gambling and choice, a useful way to represent these matters is by putting characters to the test. Thus, The Merchant of Venice combines three tests from folklore: the lottery of the three caskets; a macabre court case whereby the contractor seeks a pound of flesh as his forfeiture; and a doubled and generally disregarded ring plot. It is the middle trial that has come to dominate the drama in both audiences' and critics' minds. Shylock, and his insistent demand for the justice of his bond and thus Antonio's flesh, understandably rings loudly in the ears of all who encounter Shakespeare's work. Like the other tests in the play, it meets the criterion of having a reward/punishment structure. Shylock seeks the enforcement of his contract - the right to take a pound of Antonio's flesh - and Antonio seeks the dissolution of the grisly bond. Antonio's punishment if he fails is self-explanatory; Shylock's is less clear but likely to be unpleasant, Jews not being afforded the same rights as Christians in Venice.

In the trial scene Shakespeare has Shylock's contract rebound on him, as the test motif does in the other plays, but particularly in All's Well That Ends Well. As Portia weighs the merits of Shylock's bond, she explores the values of justice and mercy. Thus the trial scene, Marjorie Garber argues, operates to some degree as a touchstone for testing Christian nature. ${ }^{124}$ This is very different from the tests in The Taming of the Shrew, All's Well, and indeed the other tests of The Merchant. The trial scene's test of values is motivated by hatred, prejudice and revenge. This is diametrically opposed to the tests of love, mutual regard and fidelity that take place during the quest for harmonious marriages for all that these are equally serious concerns. Because it tests Christian nature, the trial scene is less concerned with testing worthiness. The audience are positioned to see Shylock as the unworthy villain, despite his cry for his humanity to be recognised. It is fundamentally inhumane, albeit fitting for someone characterised as currish, to seek a man's flesh. Similarly, Antonio is portrayed as the victim, although not an entirely innocent one. Ultimately we must recall that the play is a comedy; the testing of the bonds of love

${ }^{124}$ Garber 283. 
must cancel out Shylock's bond of hate. ${ }^{125}$ Therefore this chapter will focus primarily on the tests which are imposed to prove worthiness - the three caskets and the ring plot - to examine what Shakespeare does with folk-tale.

Together the casket plot and ring plot provide an overarching structure to The Merchant of Venice that has not been sufficiently recognised by critics. Shakespeare toys with his audience in prolonging the testing sequence: introducing Portia's weariness of the casket lottery early in Act 1; making it clear in Act 2 that neither the gold nor silver casket is the right one when the Princes of Morocco and Arragon fail to choose correctly; finally having Bassanio make the now obvious choice of the lead casket in Act 3. The object that symbolises the resolution of the lottery then becomes the source of its own test. Portia presents a ring to Bassanio as a sign of their relationship, and of all that she bestows upon her new husband: "This house, these servants, and this same myself, / Are yours, my lord's. I give them with this ring" ${ }^{126}$ As one task ends another begins, and the quotation continues just as seamlessly from its enjambed line: "Which, when you part from, lose or give away, / Let it presage the ruin of your love, / And be my vantage to exclaim on you" (3.2.172-4). The former flows into the latter.

Portia's father's death-bed inspiration for the lottery of the three caskets is designed to protect his only daughter and heir from feckless fortune hunters and instead reveal a worthy husband. Nerissa provides the audience with the background to the task's inception:

Your father was ever virtuous, and holy men at their death have good inspirations. Therefore the lottery that he hath devised in these three chests of gold, silver and lead, whereof who chooses his meaning chooses you, will no doubt never be chosen by any rightly but one who you shall rightly love. (1.2.26-31)

With these words, Nerissa seeks to reassure her mistress who is understandably anxious about the outcome of the lottery. Portia feels that her "will" is "curbed" (23) by her father's

\footnotetext{
${ }^{125}$ See Anthony Brennan, Shakespeare's Dramatic Structures (London: Routledge and Kegan Paul, 1986), 44.

${ }^{126}$ William Shakespeare, The Merchant of Venice, ed. John Drakakis (London: Methuen Drama, 2010), 3.2.170-

1. All subsequent references to this play will be from this edition and cited parenthetically.
} 
last will. So just as her potential husband's future is secured by the caskets, hers is also determined in this development of the motif.

The testing cycle is thus established by the last will and testament of Portia's dead father. Suitors from far and wide travel to seek their fortunes by gaining fair Portia's hand. However, the stakes are high. There is a two-step process to the lottery of the three caskets, and the first step is to choose whether to choose at all. This has been a stumbling block for the first wave of suitors Portia and Nerissa mock mercilessly in Act 1 , Scene 2 . The Neapolitan prince, the Count Palatine, Monsieur Le Bon, Baron Falconbridge, a Scottish Lord, and the Duke of Saxony's nephew have all decided not to enter into the casket test, because if they choose incorrectly, the men are "Never to speak to lady afterward / In way of marriage" (2.1.41-2). Charlotte Artese argues that this prohibition is Shakespeare's original contribution to the casket motif. ${ }^{127}$ The men's suit will be a cold one indeed for if they do not choose the right casket their future is bound to barrenness: no dowry, no wife, no heirs. By failing at the first hurdle, these men establish themselves as fundamentally unworthy, and thus the casket lottery can already be seen to be an appropriate means of sorting the wheat from the chaff.

We are then introduced to two suitors who are prepared to take the risk and submit themselves to the choice of the three caskets. By protracting the testing process of the three casket lottery, Shakespeare spins out a well-worn tale. Even if audiences weren't familiar with this particular version of a folk-tale test, they would certainly recognise that due to the common folk device of the law of three the third suitor will be the successful one, and the most modest casket will be the correct choice. ${ }^{128}$ In this instance Shakespeare confirms audience expectation with Morocco choosing the gold casket and Arragon the silver, and builds tension as we are yet to have the worthy suitor present himself. However, in addition to heightening drama and acquainting the audience with the necessary plot information such as the inscriptions on the caskets themselves, Artese argues that one of Shakespeare's purposes in drawing out this sequence is not to make obvious to the audience which casket is the right one, but to make it obvious to Portia. ${ }^{129}$ Even more than

\footnotetext{
${ }^{127}$ Charlotte Artese, "'You Shall Not Know': Portia, Power and the Folktale Sources of The Merchant of Venice," Shakespeare 5 (2009). Web. 26 August 2012. <http://dx.doi.org/10/1080/17450910903374543>, 329.

${ }^{128}$ See Artese 329.

${ }^{129}$ Artese 330.
} 
this though, in drawing out the testing sequence Shakespeare centralises the testing motif and its key idea of choice. Choice reveals innate character and, most pertinent to the casket lottery, reveals worthiness - something Morocco and Arragon lack. The objects and the messages on the scrolls within the caskets confirm this. In choosing the gold casket, the Prince of Morocco reveals his pride in wishing to possess "what many men desire" (2.7.37), and also his fundamental lack of wisdom. The scroll chides him "Had you been as wise as bold / ... / Your answer had not been inscrolled" $(70,72)$. There is clearly a pun on the Prince of Arragon's name. He does not want to choose what "many" men desire, he wishes to prove himself socially superior: "I will not jump with common spirits / And rank me with the barbarous multitudes" (2.9.30-2). Instead, he "assume[s] desert" (50) and chooses silver, but this only proves that what he deserves is a fool's head. He lacks substance: "There be fools alive iwis / Silvered o'er, and so was this" (67-8). Because of his arrogance, the Prince is unable to distinguish between outward appearance and inner reality. Thus the caskets are a highly accurate diagnostic tool that reveals character flaws and, as a consequence, denies the unworthy.

As Arragon exits sans wife, a Messenger enters and announces the arrival of a "young Venetian" (2.9.86) who seems "So likely an ambassador of love" (91). Nerissa realises that this new suitor must be Bassanio (see 100) as she reminded Portia of him earlier, considering him "of all ... men ... the best deserving a fair lady" (1.2.112-4). The audience are therefore firmly encouraged to move beyond their initial impression of Bassanio as a mere reckless adventurer in search of his fortune, despite the way he imagines himself as a Jason in quest of his golden fleece (see 1.1.169-74). Nerissa's esteem of Bassanio is crucial in re-framing him as the worthy victor in the lottery of the three caskets and not just a spendthrift bankrupt.

In his ability to solve the riddle of the inscriptions and see beyond the materialism inherent in the choices of the gold and silver caskets, Bassanio passes the test and proves he is worthy of being Portia's husband. It is because the test is specifically designed to reveal the most appropriate future Lord of Belmont that I discount the theories espoused by some critics $^{130}$ of Portia rigging the test in her favour by having the lead-rhymed song ("bred /

\footnotetext{
${ }^{130}$ See Danson 118; Drakakis 71; John Lyon, Harvester New Critical Introductions to Shakespeare: The Merchant of Venice (London: Harvester Wheatsheaf, 1988), 93.
} 
head / nourishèd" 3.2.63-5) playing in the background as Bassanio muses on the choices before him. The rhymes are clearly contrary to the purpose of the test, as well as to Portia's dedication to the letter of the law. This dedication is instrumental in the trial scene where she points out the legal quibbles which mean Shylock is not able to extract his desired pound of flesh. Portia's patience in following the lottery of the three caskets to its conclusion sees her rewarded with her heart's desire: the worthy Bassanio as her husband. She confirms his position with the ring she gifts him as a marriage token with words reminiscent of Katherina's so-called submission speech in The Taming of the Shrew.

As discussed in Chapter One, Shakespeare doubles and expands the folk-tale ring plot from II Pecorone. One of the key ways he does this is by making Portia's words that accompany the presentation of the ring conditional: "when you part from..." (3.2.172, quoted in full above). This then foreshadows the tension to come, hinting at a time when Portia may well "exclaim on" Bassanio. The symbolism of the ring itself becomes very broad. It shows that the casket test is concluded and that Bassanio is now Lord of Belmont complete with the wealth, house and servants that go along with the position. The ring becomes a betrothal gift, and a sign of Portia's submission to her husband as befitting an early modern wife in a hierarchical marriage: "her gentle spirit / Commits itself to yours to be directed, / As from her lord, her governor, her king" (3.2.163-5). It also represents Portia herself, no longer the ruler of her household or the "Queen o'er myself" (169), but belonging to Bassanio as she grants him even "this same myself" (170). Bassanio appears to accept the ring and its associated symbolism with these words: "when this ring / Parts from this finger, then parts life from hence" (183-4). Here, he apparently treats the issue with the seriousness it warrants, equating his life with the bond, just as Antonio has done for him with Shylock. Through this parallel we can see further how the testing sequences within the play as a whole are interlinked, creating structure, as well as the subtext Shakespeare is able to suggest by adapting folk-tale motifs, as is the case with the tongue in The Taming of the Shrew.

Bassanio pledging his life to Portia and the exchange of the ring has a double in Gratiano's announcement that he wishes to marry Nerissa. The casket test has thus determined more than one marriage: "Your fortune stood upon the caskets there, / And so did mine too" (3.2.201-2). Bassanio and Portia happily accept this addition to the occasion 
(see 212), and Gratiano jokes about placing a wager on who will have the first born son. The good humour is immediately disrupted by arrivals from Venice who bring the news of Antonio's arrest. This prompts a swift wedding ceremony, "First go with me to church and call me wife" (302) says Portia, but does not allow time to consummate the new marriage: "For never shall you lie by Portia's side / With an unquiet soul" (304-5). Portia understands that Bassanio is unable to give himself fully to his marriage while a pound of Antonio's flesh is bound to Shylock for his sake. Portia also realises the precarious liminal state this wedding-but-not-marriage leaves her and Nerissa in: "My maid Nerissa and myself meantime / Will live as maids and widows" (308-9). They are married women without their husbands, hence like widows; but are still virgins and hence like maids. This is the space which Portia's conditional words about the ring come to occupy and ferment in, and also where the testing occurs.

The tension of the husbands who are bound to their wives but also to their friend Antonio increases during the trial scene. In their earnestness to demonstrate to Antonio how much they wish to free him from the flesh bond, Bassanio and Gratiano seem prepared even to sacrifice their wives:

Antonio, I am married to a wife

Which is as dear to me as life itself;

But life itself, my wife and all the world

Are not with me esteemed above thy life.

I would lose all, ay, sacrifice them all

Here to this devil, to deliver you. (4.1.278-83)

So proclaims the newly-wed Bassanio, unknowingly directly in front of the wife he is apparently quite willing to forgo. Portia, disguised as a lawyer, understandably warns her husband that "Your wife would give you little thanks for that / If she were by to hear you make the offer" (284-5). Gratiano feels the same way as Bassanio: "I have a wife who I protest I love. / I would she were in heaven, so she could / Entreat some power to change this currish Jew" (286-8). Nerissa, as the lawyer's clerk, also points out the friction this sentiment could generate "'Tis well you offer it behind her back, / The wish would make else 
an unquiet house" (289-90). For me this moment lends strong motivation to the ensuing and significant ring plot where the wives need to test their husbands to determine how genuine the relationship between the respective couples is. Who will the husbands put first: their friend or their wives?

The men's rings now come to represent something more. In keeping with the monetary concerns of the play, the rings become payment for services rendered; a commodity to be exchanged. Bassanio offers the cunning lawyer the money due to Shylock as thanks. The lawyer requires no such payment, but when pressed to take some token as a tribute, asks for Bassanio's gloves and then his ring. Initially Bassanio evades the request by calling the ring a "trifle" (4.1.426), but when pressed admits "There's more depends on this than on the value" (430). It seems Bassanio is determined not to part with the ring, even at risk of appearing ungracious. It is not until Antonio intercedes and pleads for the lawyer to "have the ring" (445) that Bassanio sends it to Portia with Gratiano. This messenger-act of Gratiano in turn prompts Nerissa to "see if I can get my husband's ring, / Which I did make him swear to keep for ever" (4.2.13-4), further complicating the ring plot beyond its original sources.

With their husbands' rings back in the wives' possession, further symbolic layers are added to the already well-laden objects. As the women leave the men to twist in the wind, the sexual symbolism of rings comes into play. John Drakakis glosses "ring" by explaining that "there is a tension between the ring as a symbol of marital unity and chastity and the sexual meaning of vagina". ${ }^{131}$ A good example of this is in Portia's line "I'll die for't, but some woman had the ring!" (5.1.208) This draws on the common Elizabethan pun on 'death' as an orgasm, and we will see this pun and these layers of meaning at work also in All's Well That Ends Well. The women firstly accuse the men of giving the rings away to a lover, and then allow their husbands to believe that they themselves have slept with the lawyer and his clerk before the husbands have even had a chance to consummate their own marriages. In continuing the joke for over a hundred lines, Portia and Nerissa substantially raise the spectre of female infidelity and cuckoldry. However it is Antonio, allowing himself to be bound once more for Bassanio, who nudges the ring plot to its conclusion. Portia agrees that Antonio can act as an intermediary between herself and Bassanio, and he ${ }^{131}$ Drakakis 382. 
returns the ring to its rightful owner: "I dare be bound again: / My soul upon the forfeit, that your lord / Will never more break faith advisedly" (5.1.251-3). However the threat of female infidelity is not so easily laid to rest, as evidenced by the final line of the play, Gratiano's exclamation that "while I live, I'll fear no other thing / So sore as keeping safe Nerissa's ring" (306-7). Presumably Bassanio will have the same worry to contend with in the afterlife of the play, just as Portia may well continue to worry about where her husband's true loyalties lie. The complication of the ring plot thus epitomises Shakespeare's use of folk-tale.

While testing is clearly a central aspect of The Merchant of Venice, the testing of Bassanio in particular, as of Katherina in The Shrew, is the primary focus of the imposed tasks. This is fitting considering the argument some critics make based on the possible etymology of the character's name. Russell Astley cites Northrop Frye, who states that "it is fitting that the name of the only suitor to judge truly among the symbolic metals should resemble a Greek word for touchstones (basanoi)."132 Holmer concurs: "one theory is that 'Bassanio' derives from the Greek 'basanos' for touchstone." ${ }^{133}$ The OED seems to confirm this idea: the mineral name for "touchstone", basanite, comes from the Greek word for touchstone also meaning "test". ${ }^{134}$ The argument becomes persuasive. In terms of Bassanio, the idea can operate in two ways. It is obvious that he is put to the test. His ability to choose correctly amongst the three caskets is directly linked to the testing of his worthiness to be Portia's husband. However, Holmer also argues that Bassanio "is metaphorically presented as the human touchstone for testing the quality of love". ${ }^{135}$

Following Holmer's contention is fruitful: Bassanio certainly inspires a great deal of love from those around him. Antonio is literally willing to put his life on the line for the sake of his friend. Some readers have considered this alongside the undiagnosed cause of Antonio's sadness at the beginning of the play, and concluded that there could be an element of homosexual love present. ${ }^{136}$ While this may be the case, it is not pertinent to my argument and I place more emphasis on the relationship suggested by II Pecorone: one of

\footnotetext{
${ }^{132}$ Russell Astley, "Through a Glass, Darkly: Judging Hazards in The Merchant of Venice," Ariel 10 (1979). Web. 16 January 2012.

<http://go.galegroup.com/ps/i.do?id=GALE\%7CH1420063680\&v=2.1\&u=per_k12\&it=r\&p=LitRC\&sw=w>, see note 2, 34 .

133 Holmer 110.

${ }^{134}$ basanite, n. OED Online. June 2012. Web. 9 September 2012. <http://www.oed.com/view/Entry/15839>.

${ }^{135}$ Holmer 111.

${ }^{136}$ For a full discussion of this interpretation see Drakakis 51-6.
} 
strong kinship. Instead, what is of greater importance is the situation that arises elsewhere in Shakespeare, where "the arrival of the woman threatens the severance of the homosocial bond between two men, introducing division where there was once patriarchal harmony." 137 Thus, delivering what he thinks at the time will be his final words to his friend, Antonio asks that Bassanio remembers him to his wife, and instructs him to "Say how I loved you, speak me fair in death, / And, when the tale is told, bid her be judge / Whether Bassanio had not once a love" (4.1.271-3). These lines support Holmer's argument that Bassanio is a human touchstone; Antonio calls for Portia to measure their friendship and love against Antonio's own actions, but also against what she herself knows of her husband's qualities. Nerissa's valuation of Bassanio, "Bassanio, lord, love, if thy will it be" (2.9.100), referred to briefly above, does on some level equate him (or some powers he might be able to reach out to) Cupid-like, with love itself. ${ }^{138}$ He patently inspires love in Portia, who fervently wishes to delay Bassanio entering into the lottery of the three caskets in order that she might find a legitimate way to teach him how to choose correctly. In words that foreshadow the sentiments she will express when giving Bassanio his ring, Portia says that, even prior to the correct choosing of the lead casket, "One half of me is yours, the other half yours. / Mine own, I would say: but, if mine, then yours, / And so, all yours" (3.2.16-8). However, while this lodestone quality in Bassanio draws others to love him, it also means that characters feel the need to test him. How do those who are in love with him, heterosexually, platonically, or even homosexually, know where they stand in the order of his affections, or how strong their mutual bonds of affection and loyalty really are?

The testing of Bassanio, as stated earlier, is then indeed at the heart of Shakespeare's play. Proving Bassanio's worthiness provides the driving force for the first half of the drama, encapsulated as it is by the lottery of the three caskets. Nerissa points out in Act 1, Scene 2, that the man who chooses correctly will be the man Portia will love. Portia clearly comes to accept this position, telling Bassanio as he prepares to make his decision, "If you do love me, you will find me out" (3.2.41). However Shakespeare's test of

\footnotetext{
${ }^{137}$ Drakakis 53

138 This problematic line has several competing emendations, including "Bassanio Lord, love ..." and "Bassanio, Lord Love, ...". As Drakakis argues, the "problem arises because of the uncertainty of the identity of the possessive thy", and also the 'lord' "may refer, ambiguously, both to Bassanio's social status and to an unspecified paternalist deity charged with determining the outcome, and of whose power Cupid would be the agent". Drakakis' choice encapsulates the "ambiguity that arises [which] emphasises both Bassanio's own agency and the limitations imposed upon it by forces beyond his control" 279 .
} 
the three caskets is more than a mere game of chance, of "hazard". He has developed the plot device beyond that suggested by his sources to become "an act of interpretation", 139 a test of close reading skills. Bassanio must be able to determine the true meaning behind the riddling inscriptions: "Who chooseth me shall gain what many men desire"; "Who chooseth me shall get as much as he deserves"; and "Who chooseth me must give and hazard all he hath" $(2.7 .5,7,9)$. In interpreting these epigraphs, the chooser reveals something fundamental about his character, and so the caskets become a kind of "psychological test" ${ }^{140}$ As discussed earlier, the Princes of Morocco and Arragon, in choosing the gold and silver chests, reveal their pride and arrogance. Portia's father's test is indeed a successful touchstone of worthiness, and Morocco and Arragon only serve to show themselves as being unworthy of the prize of Portia's hand. Conversely, Bassanio shows himself to be truly worthy. He interprets the inscriptions correctly and is not swayed by the precious metals of the caskets: "So may the outward shows be least themselves, / The world is still deceived with ornament" (3.2.73-4). The casket test is the key way Bassanio proves himself to be worthy, and thus develops his character beyond that of Antonio's sponge. Christopher Spencer argues convincingly that "Bassanio has no other action in the play that enables him to show courage or wisdom."141 The test then operates as a plot device and a structural tool, as well as Shakespeare's way of significantly developing the characterisation of Bassanio.

The ring plot acts in a similar way. When Portia gives Bassanio the ring in Act 3, Scene 2 we are strongly reminded of the other important ring in the play: Leah's turquoise, which, as we have learnt from the immediately preceding scene, was reportedly exchanged by Jessica for a monkey. This moment appears to be Shakespeare's innovation, which increases its significance. Just as Shylock takes Jessica's flagrant disregard for her dead mother's ring as a sign of her faithlessness, Portia counteracts this moment by asking Bassanio to treat her ring as a symbol of faithfulness. Jessica has broken her faith; Bassanio must keep his. ${ }^{142}$ Thus Portia initiates a new test for Bassanio with the ring; a test of his

\footnotetext{
${ }^{139}$ Garber 288.

${ }^{140}$ Garber 288.

${ }^{141}$ Spencer 61.

${ }^{142}$ See Danson 192.
} 
fidelity. ${ }^{143}$ As his wife, Portia understandably expects that she now comes first in Bassanio's loyalties. She does acknowledge the prior bond Bassanio has with Antonio, choosing to delay the consummation of her marriage herself in order for Bassanio to have time to rectify the macabre situation Antonio is in due to that bond. This situation is notably different to both The Taming of the Shrew and All's Well That Ends Well as in these plays it is the men who decide to stay the consummation of their new marriages. When, disguised as the lawyer Balthazar, Portia hears her husband place Antonio before her, willing to sacrifice his wife for the sake of his friend, it becomes clear that Bassanio's priorities need adjustment for a happy marriage to be forged. As John Lyon rightly summarises, "symbolically, the ring exposes a division of loyalties, a failure of absolute fidelity and a tension between different obligations and bonds." ${ }^{144}$ In this, Keith Geary argues, the ring plot becomes a kind of reenactment of the trial scene, substituting the marriage bond for the flesh bond. ${ }^{145}$ However the tension is even greater than that suggested by Geary because it is heightened by the inherent symbolism of the ring, whereby man and wife become 'one flesh' during the wedding ceremony. Even more than this, while Bassanio and Portia have married, they have not yet had the chance to become 'one flesh' because, as stated earlier, their consummation has been delayed because of the previous 'flesh bond' Bassanio has become entangled in.

With all these complicated cross-currents in play, flowing from Shakespeare's intricate re-shaping of folk-tale motifs, it is unsurprising perhaps that initially Bassanio fails his test. In seeking to preserve his faithfulness to his wife, Bassanio gallantly refuses to hand his ring over to the lawyer who seeks it: "Good sir, this ring was given me by my wife, / And when she put it on she made me vow / That I should neither sell, nor give, nor lose it" (4.1.437-9). Unfortunately he then undoes his good intentions when pressed by Antonio and sends the ring after the lawyer (see 4.1.445-7). By surrendering to Antonio's wishes, Bassanio proves Portia's suspicions: he places his friendship with Antonio before his marriage to Portia. ${ }^{146}$ He still has a lesson to learn.

\footnotetext{
${ }^{143}$ See Drakakis 91.

144 Lyon 122.

${ }^{145}$ See Keith Geary, "The Nature of Portia's Victory: Turning to Men in The Merchant of Venice," Shakespeare Survey 37 (1984), 66.

${ }^{146}$ See Spencer 2.
} 
We see then, that Barber couldn't be more wrong in describing the ring plot as a "slight business". ${ }^{147}$ Shakespeare develops the motif considerably: it grows out of the casket test which occupies the first half of the play, and comes to dominate the second half once the trial scene is concluded. The resolution of The Merchant of Venice is contingent upon the resolution of the ring test. The overriding tone as the ring plot moves its way to its resolution is a light-hearted one; however, it is also accompanied by deep, underlying concerns. The women raise the spectre of infidelity in this final scene of the play in three ways. Firstly, Portia accuses Bassanio of passing the ring on to "some woman" (5.1.208). Then she threatens to sleep with the lawyer who is now in possession of her ring: "I'll have that doctor for my bedfellow" (233). Finally, to explain how the ring has come back to them, Portia and Nerissa tell their husbands that they have slept with the other men: "For by this ring the doctor lay with me" (259), says Portia; "the doctor's clerk, In lieu of this [ring], last night did lie with me" (261-2), mimics Nerissa. As the men begin to fear they have been cuckolded before they've even had a chance to enjoy their brides, Portia magically produces a letter which she says will explain that she and Nerissa were the lawyer and his clerk all along. This section of the play is riddled with sexual innuendo, not least of which is the sexual symbolism of the rings, as discussed above. For example, Portia warns Bassanio not to let the lawyer "e'er come near my house! / Since he hath got the jewel that I loved" (223-4). This plays on the idea of the ring itself being a jewel, but also that the "jewel" represents her virginity, an image which we will see again in All's Well. Gratiano threatens to "mar the young clerk's pen" (237) when he learns his wife has supposedly slept with him, threatening to literally damage his main occupational tool, his quill, but also his penis. There is plenty of dramatic irony and thus humour for the audience also, who know the full story of the constructed ring plot as well as the cross-dressing measures the women have employed: Nerissa can quite honestly say "The clerk will ne'er wear hair on's face that had it" (158).

In playing on the men's fears of infidelity, Shakespeare is able to use folk-tale to have Portia and Nerissa tap into the cultural anxieties of Renaissance men. This reminds us of Petruccio's concerns to be seen as being in control of Katherina's tongue as the signifier of her sexuality in The Taming of the Shrew. "What, are we cuckolds ere we have deserved it?"

${ }^{147}$ Barber 186. 
(5.1.265) cries Gratiano. He uses the loaded term again just a moment later (see 281). These anxieties provide the context to Gratiano's final line as he feels that he is going to continue to worry about "keeping safe Nerissa's ring" (307). These words can be taken literally: Gratiano will ensure that he does not part with his wedding ring again, but also metaphorically: Gratiano will continue to worry about being made a cuckold by Nerissa's future infidelities. Bassanio's final words on the matter are similarly light-hearted, but likewise reveal a suspicion that Portia will sleep elsewhere in his absence: "Sweet doctor, you shall be my bedfellow. / When I am absent, then lie with my wife!" (284-5) We are left with the overwhelming feeling that while the ring plot has indeed been resolved, it is only resolved for now.

The bawdy jokes heavily relied on in this final Act not only have the offstage audience in mind, but also an implied onstage audience of Antonio. I agree with Geary that Portia's focus on infidelity emphasises the sexual relationship that is to exist between herself and her husband. By asserting this sexual claim over Bassanio, Portia implicitly excludes Antonio. ${ }^{148}$ This could be read as especially cutting if one adheres to the theory of Antonio's homosexual love for Bassanio. Furthermore, she underscores this exclusion by making Antonio the conduit for the return of Bassanio's wedding ring. The pound of flesh bond which not only bound Antonio to Shylock but Bassanio to Antonio has been broken. The consummation of Bassanio and Portia's relationship is about to take place, replacing the pound of flesh bond with the 'one flesh' marriage bond. Ultimately Antonio has been trumped in Bassanio's affections. Thus, Portia instructs Antonio to "be [Bassanio's] surety" (5.1.254). The only involvement Antonio is to have with Bassanio now is to stand as guarantee for Bassanio's future fidelity, in other words to keep Bassanio bound to Portia first and foremost and in perpetuity.

Thus, transformation has been required of Bassanio through undergoing the two folk-tale tests. He has had to learn to put his wife before his friend and has been rewarded with marital and social harmony as a consequence. The tests then not only provide dramatic motivation and structure to the play, but also serve to centralise the idea of choice. Bassanio has already chosen the correct lead casket and proven himself worthy, but he must continue to do so. In order to maintain the newly acquired harmony, the ${ }^{148}$ Geary 66. 
metaphorical choice of the lead casket must be "repeatedly reaffirmed"149 and the ring kept safe, which implies that there is yet more testing on the horizon.

Just as Bassanio undergoes a transformation, Portia also experiences a "conversion" (see 3.2.166-7). Initially Portia is confined, figuratively and almost literally, by her father's lottery of the three caskets. She is confined in the sense that her image is contained within the lead casket, and the portrait becomes equated with Portia herself: "I am locked in one of them" (3.2.40) she tells Bassanio. Her virginity and thus her sexuality are also confined by the caskets; without a suitor choosing the correct casket Portia is doomed to live and die alone, just as the unsuccessful suitors who choose incorrectly are: "I will die as chaste as Diana, unless I be obtained by the manner of my father's will" (1.2.101-3) she sighs. The word "will" here highlights the multifaceted nature of the casket test. Portia is restricted because of the conditions imposed on her by her father's last will and testament; it is also her father's desire, his will, that his daughter's husband is chosen by this method; and the construction of the verb form in contrast to the noun points to Portia's "will", her wish and sexual desire being in opposition to that of her father's wishes. Thus Portia is tested alongside her suitors. She is tested in her ability to curb her desire for personal agency, not unlike Katherina in The Taming of the Shrew, which confirms Shakespeare's technique of expanding his folk-tale sources. As William Carroll argues, Portia is required to be patient and passive ${ }^{150}$ and submit her personal desires to the will of her dead father.

So when Bassanio opens the lead casket to reveal Portia's picture, she too is released from the confines of the casket test. Portia calls this moment her conversion. No longer a virgin daughter but a soon-to-be married wife, Portia is indeed converted from one state to another. The ring that is presented to Bassanio at this stage is a sign of Portia's change in status. Furthermore, Portia's will and agency are no longer confined once the lead casket is opened, and become increasingly employed in the ensuing scenes. Even in the arrival of Antonio's letter, which necessitates the delay in the consummation of her marriage, does Portia exercise control. By choosing to postpone the consummation, Portia demonstrates personal control of her sexuality. Further, she uses imperatives to direct the action that

\footnotetext{
149 Holmer 264.

${ }^{150}$ See William Carroll, The Metamorphoses of Shakespearean Comedy (New Jersey: Princeton University Press, 1985), 119.
} 
unfolds: "Pay him six thousand and deface the bond"; "go with me to church and call me wife, / And then away to Venice"; "Come away, / For you shall hence upon your wedding day. / Bid your friends welcome, show a merry cheer" (3.2.298, 302-3, 309-311). The new Lord of Belmont rapidly leaves 'his' new estates, leaving Portia once more in charge of her own properties. These she directs into Lorenzo and Jessica's hands, which leaves her free to embark on her own mission: "We'll see our husbands / Before they think of us!" (3.4.58-9) she tells Nerissa. Portia and Nerissa then undergo a further dramatic conversion, that of women into men.

Dressed as men, Nerissa and especially Portia take centre stage during the trial scene. Portia, as the young doctor of law, directs the course of the trial and becomes the means by which Christian justice is delivered. Her voice is a powerful one and, because it is presented as coming from a male, is unquestioned. I have argued that Portia receives the clear motivation for the test that will become the ring plot in this scene. Shakespeare's expansion of the ring test also provides Portia with a method of prolonging the exercise of her agency, so long denied due to the casket test. She has been willing to give her power, estate and money to Bassanio as the new Lord of Belmont, but circumstances lead her to ways in which she can both be the Lady of Belmont, a wife to Bassanio, and retain aspects of her independence. The ring test falls into this latter category, particularly when we bear in mind that setting a test for someone instigates a power imbalance, implying as it does that one sits in judgement over another. Shakespeare is certainly able to add depth to the ideas of the play by utilising folk-tales.

Critics such as Garber and Richard Hillman have argued that Portia's ring test anticipates the bed-trick device used in the so-called problem plays. We shall see in the next chapter how a ring plot forms part of the bed-trick Helena employs in order to fulfil the tasks imposed on her by Bertram in All's Well That Ends Well. Similarly by claiming that she has the ring Bassanio gave away back in her possession because she slept with the lawyer who was gifted it, Portia is able to appear as if she has played a bed-trick. ${ }^{151}$ This connection between the two devices, to borrow Leah Scragg's term, "encrusts" them with meanings Shakespeare is able to exploit. In appearing to have played a bed-trick, as I have discussed, Portia raises the threat of infidelity; causing her husband to think she has been unfaithful to

${ }^{151}$ See Garber 619. 
him prior to the consummation of their marriage. Furthermore, Hillman argues that Portia draws on a "traditional female source of power - the ability to make cuckolds." 152 While Bassanio is the intended subject of the ring test, as his ability to put his marriage before his friendship is determined, and Antonio is positioned to stand as Bassanio's future "surety" of his fidelity, Portia seems to warn Bassanio that just as he seemingly easily gave away his ring, she could similarly easily give away her "jewel": her chastity in marriage.

The sexualised language of the play as a whole, and not just the bawdy jokes of the final Act, reveals a fear of female sexuality, which we have also seen in The Taming of the Shrew. It is this sexuality that Portia both seems to threaten with and comes to embody. Remembering that The Merchant of Venice first and foremost revolves around money and commodities, the equation of usury to prostitution as parallel types of unnatural breeding is highly relevant here. When Shylock cites the Biblical story of Jacob and Laban as justification for his practice of charging interest on his loans, Antonio asks "is your gold and silver ewes and rams?" To which Shylock replies, "I cannot tell, I make it breed as fast" (1.3.91-2). Portia has blonde hair, "her sunny locks / Hang on her temples like a golden fleece" (1.1.169-70), but throughout the play gold is imagined as dubious and personified as promiscuous. Bassanio speaks of golden hair when he is thinking through his choices of the three caskets: "those crisped snaky golden locks, / Which maketh such wanton gambols with the wind" (3.2.92-3). Here blonde hair is equated with snakes with clear allusions to the serpent in the Garden of Eden and so the Devil. Similarly, the hair is imagined dancing lasciviously with the wind. Even when Bassanio has chosen the correct lead casket and revealed Portia's portrait, he comments aloud that "Here, in her hairs, / The painter plays the spider and hath woven / A golden mesh t'entrap the hearts of men / Faster than gnats in cobwebs" (3.2.120-3). This characterises Portia as a kind of seductress or temptress, and her golden hair is a crucial signifier of this. If a director were to choose a golden ring for Portia to present to Bassanio, the nexus of images would come together perfectly and further highlight Shakespeare's use of folk-tale to explore this idea. Gold is sexually dubious. Women are sexually dubious. Portia, with her blonde hair and as a female

${ }^{152}$ Richard Hillman, Shakespearean Subversions: The Trickster and the Play-Text (London: Routledge, 1992), 115. 
character, feeds directly into this cultural anxiety when she pretends to cuckold Bassanio a cuckold.

From the realistic threatening figure of the wanton, Portia becomes a romance figure of restoration at the end of Act 5, Scene 1. Once she is reassured that Bassanio's fidelity has been transformed, or transferred rather, from Antonio to her as wife, Portia makes it known that she is in possession of letters that confirm her imposture as the lawyer and Nerissa as the clerk, and reveal that Antonio's ships have all come magically to safe harbour. She directs those present into the house where she promises to answer all questions "faithfully" (5.1.299). It seems highly appropriate that Portia's final word should be one of fidelity. Antonio has promised to bind even more than his flesh - his very soul now - in surety for Bassanio's loyalty, but who stands as surety for Portia's?

As we have seen, Bassanio, just like the lead casket he chooses correctly, is a touchstone of fidelity in the play. The caskets are a means by which worthiness in suitors is tested, and Bassanio is a means by which loyalty in love can be tested. By Bassanio being the primary intended subject of both the casket and ring tests, Shakespeare exploits the folk-tale motif to centralise the idea of choice in the play. To choose is to make a decision between various options. Choosing reveals innate qualities and intended pathways. It is the nature of choice, particularly in these comedies, to reveal the adjustments characters are prepared to make. For Bassanio, the adjustment is shifting his loyalties from Antonio to his wife. I have argued that Portia also has an important role to play in the tests - testing is never just one-sided when Shakespeare employs the motif - her choice of exercising her agency is also tested. In the lottery of the three caskets, she chooses to abide by the will of her dead father and restrain her desired independence. But once her will is no longer contained by the lead casket, she exercises her agency liberally. She defers consummating her marriage; cross-dresses as a lawyer; breaks her husband's flesh bond to his friend; and threatens him with her sexual power. Portia tests the extent to which Bassanio will be bound to her in marriage with the ring plot before, theoretically at least, putting the spectre of female infidelity to rest and accepting being contained once again, this time by the wedding ring. This has one final symbolic element - as a sign of harmony. Diana O'Hara 
comments on the "seeming constraint imposed by its circularity", 153 and Danson sees the play moving from discord to harmony in its "dominant figure" of the "circle, ring, or round." 154 However the ambiguity of the final lines ends the play on an uncertain note; there is a void in the centre of a ring. Bassanio's fidelity seems guaranteed by Antonio, but Portia, for all that her final word is one of fidelity, does not give Bassanio any such reassurance. Gratiano may well be speaking for more than just himself when he speaks aloud his fears of keeping safe Nerissa's ring. Shakespeare's use of folk-tale sources lead us to consider how the nothing at the heart of a ring - or the "no-thing" that is an Elizabethan pun for vagina - can be possessed or controlled. Ideas of fidelity and infidelity, submission and agency are raised contrapuntally. The stability of Bassanio's transformation seems more assured than Portia's conversion.

\footnotetext{
${ }^{153}$ O'Hara 83.

${ }^{154}$ Danson 38.
} 


\section{Chapter 4}

\section{Prince Charming: All's Well That Ends Well}

Shakespeare's All's Well That Ends Well is similar to the other plays examined so far in that it employs the folk-tale motif of the test to prove worthiness, but the play subverts the motif to a much greater extent and much more overtly than previously seen. All three plays generate their own ambiguities and tensions, particularly around the issue of fidelity, and the folk-tale tests are often found at the heart of these moments. In this, All's Well is no exception through its use of the impossible tasks Helena has imposed on her by Bertram. However Shakespeare also expands the testing beyond a plot device. In The Taming of the Shrew and The Merchant of Venice we are presented with multiple examples of tests and broader educative contexts, but in All's Well the testing comes to take over the play as a whole in a way that doesn't occur in the other texts. In All's Well the testing of characters allows Shakespeare to use the motif to test genre itself. ${ }^{155}$ In this play, the folk-tale and real world compete on a more explicit level than, say, Belmont and Venice in The Merchant. The tasks, and the bed-trick which is the key to achieving them, are central to the many questions this play raises for its onstage and offstage audiences.

Alexander Leggatt's argument, which I strongly agree with, is that in the play "the values of romance are tested in a world of down-to-earth and often unpleasant realism" and as such its characters should be examined as "creations springing from, and inextricably wedded to, the peculiar dramatic mode of the play."156 Recalling the OED definition of romance as a narrative depicting sensational or exciting events, ${ }^{157}$ we can say that in All's Well Helena operates as if she is a character in a romance and thus understands her imposed tasks as folkloric, achievable if she is worthy, whereas Bertram operates as if he is a character in a realistic drama and thus fully intends that the test for his wife will be literally impossible for her to complete. This moves the play beyond mere folk-tale, as suggested by

\footnotetext{
${ }^{155}$ See Leggatt, "Testing of Romance" 22.

${ }^{156}$ Leggatt, "Testing of Romance" 22.

157 See Chapter One, 13.
} 
Lawrence. ${ }^{158}$ As in The Shrew, the romance elements in All's Well should not be used to excuse away its tensions.

The testing is broad in All's Well, more than just the major example of the impossible tasks Bertram sets for his new bride. Prior to this central moment, Helena has to first become Bertram's wife and to achieve this she must overcome the barrier of distance. Right at the beginning of the play, following his father's death, Bertram moves from his home estates at Rossillion to Paris to be the King of France's ward. This prompts grief in Helena, already in mourning for the loss of her own father, a famed doctor. However the conflation of circumstances and the news of the King's seemingly incurable illness, suggest to Helena a path she might take: "Who ever strove / To show her merit that did miss her love? / The king's disease - my project may deceive me, / But my intents are fix'd, and will not leave me". ${ }^{159}$ Here, the final words of Helena's soliloquy intimate the way that her intended "project" could operate as a self-imposed test to prove her "merit": that she is worthy of Bertram's love. They also serve as evidence of her functioning in a romance mode: she fully expects that in demonstrating her "merit" she will be rewarded with her heart's desire, Bertram. The romance mode develops further when Helena convinces the King to allow her to try the remedy she has learnt from her late father. She is willing to put her life on the line, so convinced is she of the potency of the cure. On the other hand, if she succeeds, she demands of the King, "Then shalt thou give me with thy kingly hand / What husband in thy power I will command" (2.1.192-3). She bargains with her medical knowledge for the right to choose herself a husband. And in line with both romance and folk-tale expectations, she succeeds.

Helena wins herself the prize and is presented with various eligible bachelors to choose between. She politely rebuffs each one, but then comes to Bertram. Rather than choosing him, she modestly offers herself: "I dare not say I take you, but I give / Me and my service, ever whilst I live, / Into your guiding power" (2.3.102-4). Here Helena conforms with courtly love conventions, offering herself in service to the one she loves. In line with his realistic mode, Bertram coldly rejects her on the basis of her supposed lowly status. The

\footnotetext{
${ }^{158}$ See Chapter One, 11.

${ }^{159}$ William Shakespeare, All's Well That Ends Well, ed. G. K. Hunter (London: Cengage Learning, 2007), 1.1.2225. All subsequent references to this play will be from this edition and cited parenthetically.
} 
King of France, who feels slighted as he has recognised Helena's worthiness and has awarded her sufficient wealth to be regarded as being at an appropriate social level, is infuriated by this turn of events. Consequently he essentially forces Bertram to marry Helena immediately (see 2.3.178-80). The King overriding the important issue of Bertram's consent to the marriage prompts the central test of the play, the impossible tasks.

Bertram makes the point at least four times that he has not slept nor will not sleep with his new bride. He tells his sidekick Parolles that "Although before the solemn priest I have sworn, / I will not bed her" (2.3.265-6), and again "I'll to the Tuscan wars and never bed her" (269). He repeats the sentiment at 2.5.24-6. Bertram is even happy to make the point clear to his mother, stating in a letter "I have wedded her, not bedded her, and sworn to make the 'not' eternal" (3.2.20-1), punning on the eternal 'knot' of marriage. Legally, this is a crucial factor as consent was held by the church to be the essential element that made a marriage valid. Bertram's denial of the sexual consummation of his marriage is, as Subha Mukherji argues, his way of "holding out against the one formality that is left him to resist." ${ }^{160}$ In other words, the only power Bertram has is to withhold his consent to the marriage which has been foisted upon him and deny Helena the consummation of their union. This action shows him in a realist mode: one that rejects romance. It is particularly the tone of the statement he writes to his mother that is developed in the letter Helena receives which outlines the impossible tasks:

When thou canst get the ring upon my finger, which never shall come off, and show me a child begotten of thy body that I am father to, then call me husband; but in such a 'then' I write a 'never'. (3.2.56-9)

Thus Bertram imposes these tasks with the literal intention of a character in a realistic drama; his expectation is that Helena will not be able to accomplish them, and therefore he will not have to be her husband. With Helena and Bertram then married before the middle of the play, the impossible tasks come structurally to occupy the entire second half of the drama, as well as to embody the tension between the two characters and the two genres.

\footnotetext{
${ }^{160}$ Subha Mukherji, "Consummation, Custom and Law in All's Well That Ends Well", Shakespeare and Sexuality, eds. Catherine M. S. Alexander and Stanley Wells (Cambridge: Cambridge University Press, 2001), 120, 121.
} 
The bed-trick is the device by which Helena is able to accomplish her tasks. Fittingly for a romance character she adopts a disguise, ${ }^{161}$ that of a pilgrim, and resolves to leave Rossillion as she believes it is her presence there that is preventing Bertram from returning home, instead forcing him to risk his life fighting in the Tuscan wars. This kind of Patient Griselda-like self-abnegation is appropriate for a character who functions in a romance mode and is suggested by Shakespeare's source material. Taking the rather odd route to Spain via Italy, Helena ends up in Florence like her husband. In a double coincidence, she ends up associating with the woman Bertram is lustfully attempting to woo. The convergence of the circumstances again suggests to Helena a way in which she might take her fate into her own hands and meet the conditions Bertram has laid:

it is no more

But that your daughter, ere she seems as won,

Desires this ring; appoints him an encounter;

In fine, delivers me to fill the time,

Herself most chastely absent. (3.7.30-4)

She plots that Diana will arrange an assignation with Bertram, during which Diana will exchange 'her' ring for Bertram's ancestral ring, but that she will not actually be present during the encounter; Helena will take her place. There is an acknowledged dubiousness to the bed-trick, as indicated above by the adverb "chastely", and this will be discussed later. Shakespeare has again doubled the ring plot from his source, which allows for sexual subtext to be generated, as the role rings play in the bed-trick draw on the various connotations previously discussed in relation to The Merchant of Venice.

As Bertram is the subject of one testing plot, Parolles, his feckless companion, becomes the subject of another. The loyalty of women is juxtaposed against the disloyalty of men in this example of the testing motif. Parolles goes off pretending to hunt for a lost drum, an object which Bertram calls an "instrument of honour" (3.6.62), linking it to his own ancestral ring. He is easily captured by his own men who pretend to be foreigners and 'interrogate' him. Parolles reveals the secrets of the camp and more in the presence of

\footnotetext{
${ }^{161}$ Other romance figures who adopt a disguise, in addition to Portia in The Merchant are: the Queen in 'Snow White'; the Wolf in 'Little Red Riding Hood'; Odysseus. The Ovidian idea of metamorphosis more generally is also illustrated by the Frog Prince, Pinocchio, the Beast in 'The Beauty and the Beast'.
} 
Bertram and his fellow French lords. The lords themselves were already aware of Parolles' lack of moral fortitude; the display is actually for Bertram's benefit: "It were fit [Bertram] knew [Parolles]; lest, reposing too far in his virtue, which he hath not, he might at some great and trusty business in a main danger fail you" (3.6.13-5). The gulling of Parolles is intended to be a parallel of the bed-trick Bertram falls prey to. The gulling of one echoes the gulling of the other, and the two events are deftly spliced together to emphasise the connection.

With the bed-trick accomplished Helena has fulfilled her impossible tasks; she falls pregnant as a result of the encounter and the two rings are transposed, and this suggests the conflict of the play is resolved. However, Helena's announcement that she has met her husband's demands does not unfold smoothly. Act 5 of the play becomes increasingly convoluted as the testing of the two genres comes to a head. The ring plot plays a key role in creating the confusion, as does Diana herself with her riddling statements. Helena enters and announces that she has achieved her quest, quoting Bertram's infamous letter back to him. She asks her husband "Will you be mine now you are doubly won?" (5.1.308) While Bertram does ask for "pardon" (302), he addresses his conditional answer to the King: "If she, my liege, can make me know this clearly / I'll love her dearly, ever, ever dearly" (30910). Helena replies in an equally conditional manner. As the King summarises at the end of the play, "All yet seems well" (327). Helena has indeed completed her folk-tale tasks and, on the surface, it seems as though Bertram has accepted this and therefore accepted her as his wife. With the marriage now validated through the bed-trick and Bertram's public acknowledgement, the play reaches a resolution - but not one of the simple romance kind.

Like Katherina in The Shrew and Bassanio in Merchant, Helena is positioned as the key subject of the impossible tasks, the crucial test of the play, because the instructions come in a letter addressed to her. Although, as we have seen, there are other testing-type situations within the play, Helena's tasks occupy the drama in a way these others do not. As I have argued, tests are imposed on characters in order to prove their worthiness. By completing the tasks assigned to them, characters demonstrate their prowess in exercising their virtue. However this folk-tale baseline is subverted by Shakespeare: he has his characters in All's Well That Ends Well comment consistently on Helena's worthiness. The 
remarks are peppered throughout the play, regardless of Helena's completion of any tasks, and are spoken by characters who are themselves established as reliable moral commentators. For example, very early in Act 1, the Countess of Rossillion remarks on Helena's "honesty" and "goodness" (1.1.42). When endorsing the idea of Helena being able to cure the King, Lafew says that he has spoken with "one that in her sex, her years, profession, / Wisdom and constancy, hath amaz'd me" (2.1.82-3). The King clearly is convinced of these qualities residing in Helena because he champions them to Bertram: "If she be / All that is virtuous, save what thou dislik'st / A poor physician's daughter - thou dislik'st / Of virtue for the name" (2.3.121-4, see also 3.2.30). Helena thus becomes the very byword of virtue, a living symbol of the quality itself. Even peripheral characters know of Helena's worthiness, such as a French lord commenting that Bertram "has much worthy blame laid upon him for shaking off so good a wife and so sweet a lady" (4.3.5-6). Significantly, when the King believes that Helena is dead he obituarises her by stating that "We lost a jewel of her" (5.3.1). The metaphor here, again like the rings in The Merchant of Venice, captures ideas of Helena's valuable virtue and constancy, as the other quotes do, but particularly emphasise her chastity and her fidelity.

Therefore, in contrast to someone like Bassanio in The Merchant, Helena does not have to pass any test to prove her worthiness. The fact of it has already been established by her own actions and by the comments of trustworthy characters throughout the play. Across the three comedies then we see Shakespeare's development of the motif. Furthermore, Helena's worthiness is often commented on in opposition to Bertram's unworthiness. This seems ironic as Helena herself is unaware of any flaws; as Leggatt correctly observes, "romantic love leads to the idealization of the beloved". ${ }^{162}$ Bertram's own mother provides an excellent example of the juxtaposition:

Nothing in France until he have no wife!

There's nothing here that is too good for him

But only she, and she deserves a lord

That twenty such rude boys might tend upon

And call her, hourly, mistress. (3.2.78-82)

162 Leggatt, "Testing of Romance" 24. 
The Countess uses the term "unworthy" twice in reference to her son specifically with reference to Bertram as Helena's husband: "What angel shall / Bless this unworthy husband?" (3.4.25-6), and again at lines 29-30. Additionally, the earlier quote echoes a common derogatory assessment of Bertram as a "boy". The diction of virtue, honour and worthiness, and their opposites, is striking in All's Well. It positions the audience to empathise with the champion of romance, Helena, and conversely dislike the realism of Bertram. This further suggests that the function of the testing is not just about developing characterisation, but to question the dramatic mode of the play. It also complicates the arguments critics such as Lawrence like to make excusing the play's tensions by judging it a mere fairy-tale. When the Countess deems Bertram a "rude boy", a "rash and unbridled boy" (3.2.27); the King describes him as a "Proud, scornful boy" (2.3.151); and Parolles calls him both a "foolish idle boy" (4.3.207) and a "dangerous and lascivious boy" (212), it is not just Bertram's youth and immaturity that is emphasised. The term has moral connotations, with the word "boy" also able to mean "rogue" ${ }^{163}$. Moreover, in his final assessment of Bertram as "lascivious", Parolles goes on to explain this by calling him a "whale to virginity"; someone who "devours up all the fry it finds" (212-3). The image of Bertram's uncontrollable, animalistic sexual desires stands in direct contrast to the jewel imagery of his wife's constancy and chastity. Therefore, although Helena is the intended subject of the test, this is explicitly subverted because it is not her worthiness, but Bertram's which needs testing and proving.

In further subversion of the motif, and thus of folk-tale sources, by Shakespeare, the imposed tasks set by Bertram for his wife actually rebound on him. The testing of Helena becomes the testing of Bertram, in a development of the way that the testing of Katherina becomes the testing of Petruccio in The Taming of the Shrew. This is required because Bertram comes to essentially embody the hope of France. I agree with critics who describe the opening of the play as depicting the country in a state of decay. ${ }^{164}$ One understanding of this word is literal and physical: the Parisian court, like Rossillion, is inhabited by a number of elderly characters: the Countess, the King, the Lord Lafew. Bertram, his mother,

\footnotetext{
${ }^{163}$ David Crystal and Ben Crystal, Shakespeare's Words: A Glossary and Language Companion (London: Penguin Books, 2002), 52.

${ }^{164}$ See D. Bergeron, "The Mythical Structure of All's Well That Ends Well," Texas Studies in Language and Literature 14.4 (1972), 567; Leggatt, "The Testing of Romance" 23; Scragg, Mouldy Tales 106.
} 
and Helena are in mourning for the death of their respective fathers and husbands. The King is suffering from a nasty illness, graphically specified as a fistula. ${ }^{165}$ Out of this arises the second understanding, a figurative one of moral decay, represented by a nostalgia for the virtues of the past. The King reminisces about Bertram's late father, and there is clearly pressure on Bertram to grow into the kind of man he was: "Youth, thou bear'st thy father's face; / Frank nature, rather curious than in haste, / Hath well compos'd thee. Thy father's moral parts / Mayest thou inherit too!" (1.2.19-22). The testing of Bertram forms part of an educative process to encourage him hopefully to attain the maturity and wisdom France needs him to as a member of the next generation of nobles.

Even though Helena, as a romance character, sees God working through her when she cures the King, this is not sufficient to reverse the physical or moral decay and restore France. She claims that "He that of greatest works is finisher / Oft does them by the weakest minister" (2.1.135-6), and this lends her healing magical overtones: her "art is not past power, nor you past cure" (157). Scragg notes that the healing of a King is traditionally associated in folk-tale with the "renewal of a sick society", ${ }^{166}$ but in All's Well That Ends Well this isn't the case. Indeed, Bertram's refusal of Helena as his wife immediately following the miracle strongly supports this. Perhaps as Bassanio is in The Merchant of Venice, Bertram becomes a touchstone for the general health of France. Even once the King is well again, France's next generation is still to come into its full bloom of moral health, and Bertram's refusal of Helena and his persistence in his friendship with the patently roguish Parolles, are symptoms of decay yet to be reversed. This is further demonstrated when the King frames his expectation of Bertram to marry Helena as a test, albeit a heavily loaded one:

\section{Check thy contempt;}

Obey our will which travails in thy good;

... Do thine own fortunes that obedient right

Which both thy duty owes and our power claims;

Or I will throw thee from my care for ever. (2.3.157-62)

\footnotetext{
${ }^{165}$ Leggatt sees the King's illness as an aspect of the realism genre. See "Testing of Romance" 22.

${ }^{166}$ Scragg, Mouldy Tales 106. An example would be the Arthurian tale of the 'Fisher King'.
} 
The testing structure is clear: the King will reward Bertram with the newly wealthy Helena's hand in marriage or punish him with "revenge and hate" (164), banishing him from his protection. In the face of such a realistic power imbalance it is unsurprising that Bertram submits, but it is telling that the King must make such threats in order to get Bertram to comply. That Bertram resists is an equally telling sign of his moral ill-health and therefore the current state of ill-health in France.

Ultimately Shakespeare develops his folk-tale sources to suggest that Bertram needs to adjust his world-view, to see beyond the realist viewpoint he has adopted. This perspective has led him to befriend the epitome of false appearances, Parolles, and reject the epitome of virtue, Helena. Lafew, a member of the moral old-guard, warns against narrow-mindedness with respect to Helena's curing of the King: "They say miracles are past", "Hence it is that we make trifles of terror, ensconcing ourselves into seeming knowledge when we should submit ourselves to an unknown fear" (2.3.1, 3-6). Bertram has "seeming knowledge" of Parolles as a loyal friend, and Helena as being unworthy of the status of being his wife, but if he submits himself to an "unknown fear", then a transformation might be possible.

Perhaps it is having been on the receiving end of the King's unbalanced test that provides further motivation for Bertram to impose the impossible tasks upon his wife. As I have already argued, Bertram expects that Helena will never be able to fulfil the tasks he asks of her. In doing so, Shakespeare subverts the expectations of the romance genre by having his character set folklore-style tasks, but as part of a realistic mode with intentions of a permanent "never". Bertram's actions have already shown him to be acting as character in this kind of play. He is portrayed as a petulant child, wrestling with the expectations of his mother and his sovereign. He rejects an appropriately worthy wife. He runs off to fight in the Tuscan wars, where he embarks on a wooing campaign of Diana. This shift from France to Florence for the middle sections of the play mimics the increasing trend towards a realistic tone in the play, already established by such means as the nature of the King's illness, the earthiness of Lavatch, as well as Bertram himself. The move leaves behind the mystical site of Helena's "miracle" and in its place offers instead the false honour of Parolles and Bertram. Significantly, these two characters are tricked in Florence; thus the literal movement anticipates a hopeful figurative movement; moral education and transformation. 
The bed-trick is also emphasised by the shift from France to Italy. It is both the crucial method by which Helena accomplishes her impossible tasks, and also the means by which romance and realism are blurred. The bed-trick, with its own long history in storytelling, is both a romance device - with its incredible swap which couldn't possibly work in the real world ${ }^{167}$ - and an acknowledged sexually dubious plot, placed realistically on the level of prostitution. The financial transaction between Helena and Diana's mother to pay for Diana's role in the trick suggests this correlation. There are further aspects to the bed-trick which signal its inherently shady nature. For example there is Diana being alone with Bertram in order to arrange their liaison, and the trickery Diana uses to attain Bertram's ring. There is the lie that Bertram believes he is sleeping with Diana but is actually sleeping with his wife. He intends to deflower one virgin, one pointedly named for the goddess of chastity, but in actual fact deflowers another. Helena herself acknowledges the sin-but-not-a-sin nature of the bed-trick in her riddling about it, calling the plot "wicked meaning in a lawful deed, / And lawful meaning in a lawful act, / Where both not sin, and yet a sinful fact" (3.7.45-7). Her characterisation of the device shows that although Helena prefers to operate as a romance character, she can in fact operate across both modes. As Leggatt accurately observes "She appears to embrace the two aspects of the play's vision, and thus seems capable of bringing the play ... to a satisfactory resolution". ${ }^{168}$ However I argue that we can go one step further than this and say that Helena possesses the widened vision Bertram needs to learn, and the bed-trick is a suitable methodology for supplying this lesson.

The accompanying doubled ring exchange does not help to cleanse the bed-trick of its sexual stains; by employing it Shakespeare actually develops the dubiousness of the situation. Bertram initially resists giving Diana his ring as she requests. He calls it "an honour 'longing to our house, / Bequeathed down from many ancestors, / Which were the greatest obloquy i'th'world / In me to lose" (4.2.42-45). In countering Bertram's argument, Diana echoes his words:

Mine honour's such a ring;

\footnotetext{
${ }^{167}$ See Doniger 3.

${ }^{168}$ Leggatt, "Testing of Romance" 25.
} 
My chastity's the jewel of our house,

Bequeathed down from many ancestors,

Which were the greatest obloquy i'th'world

In me to lose. (45-9)

We see connections to The Merchant here in the layers of symbolic meaning the object comes to represent, and in the way the expansion of the motif allows for subtext to be foregrounded. Bertram's ring is his family's honour. Diana's ring, her "jewel", is her chastity and thus her family's honour. The discussion about exchanging rings is also understood as forming a marriage contract; the ring being a sign of their betrothal. ${ }^{169}$ In fact, Diana tells Bertram she intends on giving him a different ring during their later encounter which "May token to the future our past deeds / ... You have won / A wife of me" (4.2.63-5). Both Scragg and Carol Thomas Neely capture the oxymoron that is the bed-trick in calling it respectively "an appropriately tarnished agent of reclamation in a fallen world", ${ }^{170}$ and "both fraudulent and fair, both corrupt and restorative."

The bed-trick has these reformative qualities because it allows Helena to accomplish her impossible tasks and therefore it anticipates Bertram's acknowledgement of their union. Through his incorporation of the "encrusted" device, Shakespeare is able to portray a full range of rich ideas. Alongside the gulling of Parolles, which is also designed to educate Bertram, the bed-trick has the potential to be transformative. The bed-trick, as discussed above, also demonstrates that Helena can operate in the real world. We can see this too, for example, in her frank conversation about virginity with Parolles, as well as when she threatens Bertram with divorce in the final scene. The bed-trick functions in dual modes, as Helena does, and in fact to implement the trick, as Wendy Doniger would argue, ${ }^{172}$ Helena doubles even herself. She is both Helena and Diana, as well as both dead and alive. Helena has had it circulated that she has died and Bertram believes this when he goes to his assignation with 'Diana'. The bed-trick, in many ways, brings her back to life; it quickens her and makes her pregnant. Similarly, as Doniger also argues, "sexual passion is transformative

\footnotetext{
${ }^{169}$ See Mukherji 127.

${ }^{170}$ Scragg, Mouldy Tales 119.

${ }^{171}$ Neely 81.

${ }^{172}$ See Doniger 6.
} 
... it changes our view of our partner". ${ }^{173}$ When Bertram learns that he has slept with his wife and not his mistress, there is potential in this revelation for change and restoration. The play hints at this when on the learning of the news of his wife's 'death' we hear that "he chang'd almost into another man" (4.3.4). Thus the bed-trick is curative and restorative for both Bertram and Helena; it can make a marriage instead of break one. ${ }^{174}$

The gulling of Parolles becomes an echo of the bed-trick not only in that it is a plot designed to fool, but also in that it is a plot designed to be educative for Bertram. It is another step towards Bertram's required adjustment. Once Parolles has been 'captured', the French lords wait on Bertram's arrival before pursuing the trick further. Therefore Bertram is the desired audience. The First French lord says "I would gladly have [Bertram] see [Parolles] anatomiz'd, that he might take a measure of his own judgments" (4.3.30-2). Thus the purpose of gulling Parolles is not just in the sport of it; nor to open Parolles' eyes as to the kind of poseur he is, to prove his unworthiness; but to teach Bertram about false appearances so that he might learn to make better judgements about people. The bed-trick too is about false appearances: that while one body may appear to be another, it is not the same. And even though the onstage characters currently believe Helena to be dead, the audience know that this isn't the case and that Bertram will need to broaden his vision to apply this lesson fully.

Because the gulling of Parolles is designed as a mirror of the gulling of Bertram, two questions then arise: does Parolles experience any transformation as a consequence of the trick he is subjected to, and if he does so, does this transformation prefigure Bertram's? At the conclusion of his false imprisonment, Parolles soliloquises that "Simply the thing I am / Shall make me live. Who knows himself a braggart, / Let him fear this; for it will come to pass / That every braggart shall be found an ass" (4.3.322-5). Parolles has previously adopted a false appearance and resolves in future to drop this pretence and just be who he is. This does suggest an adjustment to his perspective. Additionally, when Parolles seeks out Lafew - the man who saw through his bluster and did not hesitate to mock him for it -

\footnotetext{
173 Doniger 3.

${ }^{174}$ Emily Detmer quoted in Doniger 84.
} 
Leggatt argues that this "may provide some underpinning for the mutual acceptance of Helena and Bertram in the last scene." ${ }^{175}$

Nevertheless, Bertram's behaviour in the final scene of the play severely strains the extent to which an audience can believe he has achieved a genuine transformation. The concern starts when Bertram gets rapidly engaged to another woman, Lafew's daughter Maudlin. As a token of this new bond, Bertram gives Lafew a ring for her. The ring is recognised as Helena's; the King says he had given it to her himself. Bertram, however, denies that the ring was ever Helena's, as he truthfully could, but then lies and says it was "from a casement thrown me" (5.3.93). In the face of Bertram's stiff denials, the King starts to suspect that Bertram has had a hand in his wife's demise (see 5.3.128). A messenger brings a letter from Diana, asking that the King force Bertram to honour his promise to marry her now that his wife is dead and because he has had intercourse with her. Consequently, Lafew rejects Bertram as his new son-in-law. Even once arrested, Bertram continues to lie. He initially claims that he has not slept with Diana, defaming her as "a common gamester to the camp" (187). However, he is at some loss to explain then how this 'whore' has his family ring. He finally admits that he "boarded her i'th'wanton way of youth" (210), and that the ring he has in his possession was originally Diana's. By doubling the ring plot Shakespeare creates even more complications than in The Merchant, but as in that play, the doubled plot also develops characterisation.

The confusion and dismay is then countered by the magic arrival of the once dead, now pregnant Helena. The King, doubting reality when she enters, queries "Is't real that I see?" (5.3.300) In a highly significant response, Helena replies "No, my good lord; / 'Tis but the shadow of a wife you see; / The name and not the thing" (300-2). Helena both is and is not Bertram's wife; she has achieved the impossible tasks but is yet to be acknowledged as his wife. She is both a romance heroine, and a heroine of realistic proportions. It is at this point I depart from Leggatt's argument, as I believe Helena actively chooses to operate as a romance character and encourages Bertram to move into her story. Musing on the bedtrick - "O strange men! / That can such sweet use make of what they hate, / When saucy trusting of the cozen'd thoughts / Defiles the pitchy night" (4.4.21-4) - she moves the philosophising aside, and instead anticipates that "'time will bring on summer' - / When

${ }^{175}$ Leggatt in Fraser 38. 
briars shall have leaves as well as thorns / And be as sweet as sharp." (31-3). Helena sees through realism to a place of romance where the worthy maiden will get her prince because a worthy maiden can accomplish impossible tasks.

The moment has come when Shakespeare has his folk-tale test rebound on Bertram. Will he live up to the implied conditions he unwittingly imposed upon himself: "When thou canst get the ring upon my finger ... and show me a child begotten of thy body that I am father to, then call me husband"? His response is to acknowledge that Helena is indeed "both, both" the "name" and the "thing", and he asks for "pardon" (5.3.302). Bertram is called to recognise that the impossible tasks can be fulfilled. In doing so he must concede that the impossible can indeed be possible, that in a way, there is magic in everyday life. Folk-tale and romance have their own part to play in the real world. The modes have blurred and his formerly narrow vision widens to accept this. Despite the conditionals which follow, in this instant, however reluctantly, Bertram does accept Helena as his wife. He passes his own test. Because of this it can be argued that Bertram does prove his worthiness, even though some audiences find it unsatisfactory.

In acknowledging Helena as his wife and thus accepting his status as husband, Bertram also gains a further position: father. Shakespeare is able to counter the generic expectations of comedy through the bed-trick in this play; the marriage between Bertram and Helena does not symbolise the return of the social order to harmony, ${ }^{176}$ but the unborn child certainly could. This is also a change from both The Taming of the Shrew and The Merchant of Venice, where the marriages and the about-to-transpire consummations indicate a society in a state of concord. Critics such as Hopkins have recognised the relationship in Shakespeare's comedies between marriage and society, where the unity between husband and wife is metonymic for unity in society. ${ }^{177}$ But in the case of All's Well That Ends Well, where the marriage occurs so early on, and the consummation also occurs during the course of the play, the emphasis must then come to fall on the pregnancy. There is a feeling that, for all his previous faults, Bertram will now accept his father's legacy and

\footnotetext{
${ }^{176}$ See Zitner 41.

177 "The Shakespearean 'happy' comedies do not celebrate marriage: they reveal its crucial functioning in the maintenance of society”, Lisa Hopkins, "Marriage as Comic Closure," Shakespeare's Comedies, ed. Emma Smith (Malden: Blackwell Publishing, 2004), 50. See also Astley 5.
} 
that the child will be the tipping point for this. Thus it serves as a symbol for the renewal of the next generation of France.

If the transformation of the French court is represented by the transformation of Bertram, does Helena herself undergo one? Throughout the course of the play all she does serves only to confirm the true worthiness other characters knew she had all along, and proves her ability to operate across dual modes. While she chooses to participate in a folktale mode with her supernatural curing of the King, her acceptance of the imposition of the impossible tasks, and her mysterious return from the dead, she also has a clear streak of reality to her, contemplating, for example, a way in which she can lose her virginity to "her own liking" (1.1.147). Helena appears to possess sexual power. Lafew, in bringing Helena to the King, calls himself "Cressid's uncle" (2.1.96), and appraises her medical skills to be those that could "araise King Pippen, nay, / To give great Charlemain a pen in's hand / And write to her a love-line" (75-7). There is an insinuation here that Helena's cure for the King's fistula will also restore him to sexual potency. Neely argues that there is a play on her name as the seductress or kidnap victim Helen of Troy. She says the name "carries implications of wantonness", ${ }^{178}$ and the play itself suggests the allusion when Lavatch sings in response to a request from the Countess to fetch Helena: "Was this fair face the cause, quoth she, / Why the Grecians sacked Troy?" (1.3.67-8) Regardless of the fact that Helena can be just as earthy as the characters around her, she is a constant. In another form of subversion, the play does not require transformation of Helena, unlike Katherina or Portia, or indeed Petruccio or Bassanio. While she is subjected to the folk-tale tests, she is not the real subject of them. That is Bertram.

And just as Helena's worthiness is never in question, neither is her fidelity, which is at the heart of the tests in the other Shakespeare comedies. Indeed a significant proportion of the worthiness that Helena is deemed to have is comprised of her chastity and constancy. ${ }^{179}$ This is important because of the murky nature of her bed-trick. An audience feels that some of its sexual dubiousness can be overlooked because the morally upright Helena is its instigator. Similarly there is no doubt, even though Helena has used deception

\footnotetext{
${ }^{178}$ Neely 73.

${ }^{179}$ See Kathryn Schwarz, "'My Intents are Fix'd': Constant Will in All's Well That Ends Well," Shakespeare Quarterly 58.2 (2007), 207.
} 
to conceive, that the child is definitely Bertram's. It is her constancy, both of purpose and of sexuality, that Kathryn Schwarz argues "saves a king, makes a husband, and perpetuates a patriline" ${ }^{180}$ The same cannot be said for Bertram. Unaided, his own actions call his worthiness and honour into question: his rejection of Helena; his proposal of the impossible tasks; his wooing of Diana; his parting with his ancestral ring (emblematic of his honour); his lying in the final scene. Furthermore, Shakespeare leaves it unclear whether Bertram's family ring is, in fact, returned to him. A director who created the stage business of Diana giving the ring to Helena, who in turn presents it back to Bertram, not unlike Bassanio's ring returning to him via Antonio, would be able to suggest more strongly that Bertram's honour, and therefore France's, is set on a path to restoration.

To help restore the moral health of France, Bertram requires a considerable dose of medicine. Some is given in the form of Parolles' gulling which is, as we have seen, specifically designed to improve Bertram's judgement of his familiars. More treatment is certainly applied when the impossible tasks rebound on Bertram, and he passes. Just as the gulling of Parolles is framed as being educational for Bertram, Hopkins argues that Helena herself has an "educative ability". ${ }^{181}$ She proves to Bertram that although he thought he knew her, just as he thought he knew Parolles, in fact he does not know her very well. In a literal sense, Bertram fails to recognise Helena during the bed-trick liaison, and more figuratively he has failed to recognise Helena's constancy of will to win him. When the test rebounds on him, Bertram unintentionally becomes a student at his own school, rather like Petruccio at his "taming school" in The Shrew. The French lords and Helena have intended to teach Bertram to see more clearly, but he must be able to put this unclouded vision into practice for himself. If, as a romance character, Helena has effected one miracle in curing an incurable king, then presumably she is just as capable of effecting another in making her prince charming. While Bertram's passing of his own test implies a lesson learnt, there is still the question of how pervasive this lesson about his judgement has been. If we again consider Ovid's adage that "everything changes, nothing is lost", romance and realism can co-exist, just as Helena comes to be both the "name" and the "thing" in being

\footnotetext{
180 Schwarz 224.

${ }^{181}$ Hopkins, The Shakespearean Marriage 62.
} 
acknowledged as Bertram's wife, and Bertram himself can be both the "name" and the "thing"; he can learn to flesh out the shadow of husband and father.

The unborn child is ripe with symbolism: it represents potentialities for Helena, for Bertram, and indeed for the French court. David Bergeron notes that the play moves from moral and physical decay at the start to fruitfulness at the end, ${ }^{182}$ signified by Helena's pregnancy. It is this baby, rather than the wedding or the consummation of Helena and Bertram's marriage, which represents the complete union of the couple. With the future generation of French aristocracy thus assured, the previous sense of mourning and of nostalgia for the past can dissipate. Therefore, the child represents hope in many forms. Initially, it represents Helena's hope that as she has met the conditions imposed on her by Bertram he will acknowledge her as wife and mother; then it figures the hope that Bertram will, in acknowledging his role as husband and father, live up to the legacy of his late father and be the kind of man he was morally rather than merely physically resembling him. And finally, it embodies the hope of France, to reverse the trend of barrenness and decay and herald an era of restoration and renewal, ${ }^{183}$ starting with Bertram, but continuing on through this new generation. Thus I concur with Neely's conclusion that "the marriage that is ratified at the end of the play is presented not as a joyous lovers' union but as a compromised bargain, not as a happy ending but as a precarious beginning." ${ }^{184}$ There is also hope in the unwed virgins: Maudlin, but especially Diana, to whom the King has promised - just as he did Helena - a dowry and her choice of husband: "If thou beest yet a fresh uncropped flower / Choose thou thy husband and I'll pay thy dower" (5.3.321-2).

However while the King's words presage a new beginning for Diana, they also lead us back to the disastrous beginning for Helena and Bertram. They suggest a King who has not learnt a lesson of his own, and make us worry about whether Parolles and notably Bertram have learnt anything substantial through their respective journeys. The King's words also form part of the conditional statements which epitomise the ending of the play. Bertram initiates this tone when, in answer to Helena's question as to whether he will accept her as his wife, he replies "If she, my liege, can make me know this" (5.3.309). Helena responds in

\footnotetext{
${ }^{182}$ See Bergeron 567.

${ }^{183}$ See Garber 632.

${ }^{184}$ Neely 65.
} 
kind: "If it appear not plain and prove untrue / Deadly divorce step between me and you!" (311-2) Then follows the King's offer to Diana, made on the proviso of her virginity. He continues in the same vein when he proverbially observes "All yet seems well, and if it end so meet, / The bitter past, more welcome is the sweet" (327-8). These are the final lines of the play, but the epilogue echoes these words, again referencing the title, "All is well ended if this suit be won, / That you express content" (2-3). The striking ambiguities of these final moments of the play, reminiscent in tone of both The Taming of the Shrew and The Merchant of Venice, clearly suggests that there is still doubt about Bertram's transformation, and thus ongoing testing of his judgement will be required. Leggatt persuasively concludes that "the testing of romance is a painful business, and to feel disturbed by the play is, I think, a truer response than to try to explain its tensions away, for tension and uncertainty are its very life. ${ }^{185}$ When Shakespeare's test motif is subverted to the extent that it is in this play, and there is such strain between the real and the folk-tale, perhaps this is to be expected. Leggatt's influential observation that "the folk-tale task is a symbolic way of achieving the personal adjustment that reality requires" ${ }^{186}$ gives us a sense of movement through folk-tale to get to reality. But Bertram already operates in his own narrow-minded version of reality. And Helena, who is so convincingly framed as a worthy romance character, can also already operate in reality, she just prefers not to. Bertram then needs to broaden his perspective to admit romance into view. It is Shakespeare's reshaping of his folk-tale sources that allows the test to rebound; he uses romance to examine and ultimately subvert realism. It is less that Bertram needs a reality check than that he needs a romance check, and this will require ongoing testing.

\footnotetext{
185 Leggatt, "The Testing of Romance" 41.

${ }^{186}$ Leggatt, "The Testing of Romance" 31.
} 


\section{Conclusion}

\section{Happily Ever After?}

In his excellent biography Soul of the Age, Jonathan Bate creates an image of Shakespeare as a "poet of double vision". He goes on to explain that:

William Shakespeare grew up to become the father of twins and in his work to be a mingler of comedy and tragedy, low life and high, prose and verse. He was a countryman who worked in the city, a teller of English folktales who was equally versed in the mythology of ancient Greece and Rome. His mind and world were poised between Catholicism and Protestantism, old feudal ways and new bourgeois ambitions, rational thinking and visceral instinct, faith and scepticism. ${ }^{187}$

This image of a "poised" Shakespeare who spans a bridge between old and new is also a superb metaphor for his treatment of folk-tale sources. Ancient folk-tales stand alongside more contemporary literary sources. He deftly bridges folk-tale land and real world. Therefore no apology is necessary. Folk-tale should not be used to excuse the tensions generated by Shakespeare's plays; but used to explain them. The test motif is doubled, subverted and developed specifically to create tension. Ann Thompson observes in The Taming of the Shrew a "juxtaposition of earthiness and sophistication, folktale and Ovid". ${ }^{188}$ This juxtaposition applies equally well to The Merchant of Venice and All's Well That Ends Well. Across all three plays we see the truth of Ovid's maxim that "everything changes, nothing is lost"; Shakespeare re-shapes folk-tales.

In The Taming of the Shrew, Katherina is the primary subject of both the absurd statements test and the wager of the three brides. These tests, in many respects, place the play closest to oral tradition. On a surface level, the tasks test Katherina's submission to Petruccio and therefore suggest a basic folk-tale moral: that a wife should be obedient to her husband as a hawk or a horse is to its master. However The Shrew progresses beyond this kind of one-sided test and its resultant power imbalance, refusing a simplistic

\footnotetext{
${ }^{187}$ Bate 18.

${ }^{188}$ Thompson, The Taming of the Shrew 11.
} 
interpretation. Katherina's obedience is to be tested by her control of her tongue, emblematic of her fidelity. Because Katherina's tests occur in public, Petruccio is simultaneously tested and thus the folk-tale motif starts to blur and becomes more complex. Katherina's subversion of her notorious final speech, and Hortensio's inability to learn how to tame his own shrew, call into question both the transformation Katherina has theoretically undergone, and the extent to which Petruccio's masculinity has been proven or undermined. The re-shaping of folk-tale sources in this play allows for ideas about marriage to be explored contrapuntally. An accord is reached by the couple: they exit Act 5 to consummate their marriage, but the struggle to get to this point, evidenced by Lucentio's final disbelieving line, reflects contemporary concerns about hierarchical and companionate marriage. No firm conclusion is reached, which suggests that testing will need to continue to maintain a stable equilibrium.

Bassanio is subjected to the casket test as the crucial means by which he can prove his worthiness in The Merchant of Venice. Passing the test, he gains Portia's hand in marriage, but he must then learn to put his wife first. When Portia delays the consummation of their marriage to allow for the dissolution of the bonds that bind Bassanio and Antonio, this action signals the beginning of the complication of folk-tale sources. Portia is no passive princess who will wait heaving a sigh for her absent husband in her Belmont fairy-tale castle. Instead, she cross-dresses and sees to the dissolving of the pound of flesh bond herself. In doing so she learns of her husband's disloyalty and this prompts her to fashion her own test for Bassanio. This is the only example in these three plays where a woman deliberately imposes a test on a man; thus we see that the ring plot deserves more critical attention than it has been previously awarded. Portia tests Bassanio's fidelity to her through the doubled ring plot, but also threatens him with her own sexuality. There is no straightforward folk-tale moral here. The ring becomes the symbol of the harmony which closes the play, but again, as in The Taming of the Shrew, the final lines are ones filled with ambiguity and suggest an open ending - the void in the centre of a ring. Loyalty, with its double infidelity, is encompassed by the ring of metal that surrounds it. At the end of the play Bassanio's fidelity is secured, but is Portia's?

Shakespeare most overtly subverts his folk-tale sources of the test to prove worthiness in All's Well That Ends Well. This seems appropriate for a highly complex play. 
Helena is framed as the subject of the central test, but Shakespeare takes pains to prove that this is completely unnecessary. In a substantial development from The Taming of the Shrew, the test that Bertram imposes on his new wife rebounds firmly on him; Bertram must prove himself worthy of his worthy wife. The testing is vital not only for the couple, but, the play suggests, for the good of France itself. As one of the few visible young members of the aristocracy, Bertram's transformation becomes symbolic of the transformation of the country; reversing its physical decay and moral decline. Shakespeare's subversion of folk-tale sources also allows the genres of romance and reality to be put to the test. Bertram's values as a character in a realistic drama are tested against Helena's romance values - and are found wanting. Transformation is required. The gulling of Parolles opens Bertram's eyes to false appearances. His own gulling, through the tainted bed-trick, itself both a device of realism and romance, is revelatory. It reveals Bertram's sexual passion for his rejected wife; it allows for the impossible tasks to be fulfilled; it results in the conception of his child. Unlike the two other plays, where the consummation of the new marriages is delayed until the afterlife of the drama, in All's Well the consummation is achieved during the course of the play. Thus the unborn child, rather than the solemnised marriage, symbolises the new hope for the couple and for society. Bertram comes to understand that he has tunnel vision. While passing a test is a way of demonstrating the transformation that a marriage requires, for Bertram this is less about facing up to reality than facing up to romance. He must adopt Shakespeare's own double vision. This is a lesson for the audience too - there is no simple response to All's Well.

Thus we can see that Shakespeare is indeed a "poet of double vision". His characters are not just folk-tale archetypes. The settings of his plays are not just fantastical. There is not just the one simple moral lesson to his tales. Shakespeare's re-shaping of folk-tale sources creates depth and ambiguity, and tests dovetail with this beautifully. Tests are not fixed, they rebound from the tester to the testee. Tests create a power imbalance, but because they are not stable, the imbalance shifts over the course of a play. Tests are a device of both romance and realism; thus the motif can bridge the gap between the two genres. In the three plays testing comes to have a structural function as they fall between the wedding and its consummation. As each couple reaches this point we see the transformations that have occurred through the tests to achieve this union. However, the 
nature of the transformations required and the anxieties they reveal suggest that testing will be ongoing. The Taming of the Shrew, The Merchant of Venice and All's Well That Ends Well may be seen to end happily, but there are doubts about the 'ever after'. How eternal is the wedding band? To see a ring in its entirety requires double vision: you must hold the reality of the circle of metal in mind as well as see the nothing in its centre. The two components are equally required to constitute a ring. Similarly, critics prefer the concrete proof of the literary source, but I have sought to re-position the folk-tale as an equally crucial component of Shakespeare's plays. 


\section{Bibliography}

Artese, Charlotte. "You Shall Not Know': Portia, Power and the Folktale Sources of The Merchant of Venice". Shakespeare 5.4 (2009): 325-37. Web. 26 August 2012. <http://dx.doi.org/10/1080/1745091093374543>.

Aspinall, Dana E., ed. The Taming of the Shrew: Critical Essays. New York and London: Routledge, 2002. Print.

Astley, Russell. "Through a Glass, Darkly: Judging Hazards in The Merchant of Venice". Ariel 10.2 (1979): 17-34. Web. 16 January 2012. <http://go.galegroup.com/ps/i.do?id=GALE\%7CH1420063680\&v=2.1\&u=per_k12\&it $=r \& p=L i t R C \& s w=w>$.

Barber, C. L. Shakespeare's Festive Comedy: A Study of Drama Form and its Relation to Social Custom. New Jersey: Princeton University Press, 1959. Print.

Bate, Jonathan. Soul of the Age: The Life, Mind and World of William Shakespeare. London: Penguin Books, 2009. Print.

Bean, John C. "Comic Structure and the Humanising of Kate in The Taming of the Shrew." The Woman Part: Feminist Criticism of Shakespeare. Eds. Green, Gayle, Carolyn Ruth Swift Lenz, Carol Thomas Neely. Urbana: University of Illinois, 1980. 65-78. Print.

Belsey, Catherine. "Love in Venice". Shakespeare Survey 44 (1992): 41-53. Print.

Bergeron, D. "The Mythical Structure of All's Well That Ends Well." Texas Studies in Language and Literature 14.4 (1972): 559-68. Print.

Berry, Ralph. Shakespeare's Comedies: Explorations in Form. New Jersey: Princeton University Press, 1972. Print.

Boose, Lynda E. "Scolding Brides and Bridling Scolds: Taming the Woman's Unruly Member." Shakespeare Quarterly 42.2 (1991): 179-213. Web. 8 March 2012. <http://www.jstor.org/stable/2870547>.

Brennan, Anthony. Shakespeare's Dramatic Structures. London: Routledge and Kegan Paul, 1986. Print.

Briggs, Katharine M. The Anatomy of Puck: An Examination of Fairy Beliefs among Shakespeare's Contemporaries and Successors. London: Routledge and Kegan Paul, 1959. Print.

Brooke, Nicholas. "All's Well That Ends Well." Aspects of Shakespeare's 'Problem Plays': Articles Reprinted from "Shakespeare Survey". Eds. Muir, Kenneth and Stanley Wells. Cambridge: Cambridge University Press, 1982. 10-21. Print. 
Brunvand, Jan Harold. "The Folktale Origin of The Taming of the Shrew." Shakespeare Quarterly 17.4 (1966): 345-59. Print.

---. The Taming of the Shrew: A Comparative Study of Oral and Literary Versions. New York and London: Garland Publishing, 1991. Print.

Bullough, Geoffrey, ed. Narrative and Dramatic Sources of Shakespeare Volume I: Early Comedies, Poems and Romeo and Juliet. London: Routledge and Kegan Paul, 1957. Print.

---. Narrative and Dramatic Sources of Shakespeare Volume II: The Comedies 1597-1603. London: Routledge and Kegan Paul, 1958. Print.

Carroll, William. The Metamorphoses of Shakespearean Comedy. New Jersey: Princeton University Press, 1985. Print.

Cole, H. C. The "All's Well" Story from Boccaccio to Shakespeare. Urbana: University of Illinois Press, 1981. Print.

Cressy, David. Birth, Marriage, and Death: Ritual, Religion and the Life-Cycle in Tudor and Stuart England. Oxford: Oxford University Press, 1999. Print.

---. Society and Culture in Early Modern England. Aldershot: Ashgate Publishing, 2003. Print.

Crystal, David, and Ben Crystal. Shakespeare's Words: A Glossary and Language Companion. London: Penguin Books, 2002. Print.

Dahl, Melinda, et al. "Once Upon a Time: Four Familiar Folk and Fairy Tales”. N.d. Web. 16 February 2012.

<http://cuip.uchicago.edu/wit/2000/teams/onceupon/whatisit.html>.

Danson, Lawrence. The Harmonies of "The Merchant of Venice". New Haven and London: Yale University Press, 1978. Print.

Davis, J. Madison, and Sylvie L. F. Richards. "The Merchant and the Jew: A FourteenthCentury French Analogue to The Merchant of Venice." Shakespeare Quarterly 36.1 (1985). Print.

Dolan, Frances E. "The Taming of the Shrew": Texts and Contexts. New York: Bedford Books, 1996. Print.

Doniger, Wendy. The Bedtrick: Tales of Sex and Masquerade. Chicago: University of Chicago Press, 2000. Print.

Drakakis, John, ed. The Merchant of Venice. London: Methuen Drama, 2010. Print.

Fox, Adam, and Daniel Woolf, eds. The Spoken Word: Oral Culture in Britain, 1500-1850. Manchester: Manchester University Press, 2002. Print. 
Fraser, Russell, ed. All's Well That Ends Well. Cambridge: Cambridge University Press, 2003. Print.

Frye, Northrop. "The Argument of Comedy." Shakespeare: An Anthology of Criticism and Theory 1945-2000. Ed. McDonald, Russ. Malden: Blackwell Publishing, 2004. 93-9. Print.

Garber, Marjorie. Shakespeare After All. New York: Pantheon Books, 2004. Print.

Garry, Jane. "Quest, Motif H1200." Archetypes and Motifs in Folklore and Literature: A Handbook. Eds. Garry, Jane and Hasan El-Shamy. Armonk and London: M. E. Sharpe, 2005. 248-52. Print.

Garry, Jane and Hasan El-Shamy, eds. Archetypes and Motifs in Folklore and Literature: A Handbook. Armonk and London: M. E. Sharpe, 2005. Print.

Geary, Keith. "The Nature of Portia's Victory: Turning to Men in The Merchant of Venice." Shakespeare Survey 37 (1984): 55-68. Print.

Georges, Robert A. "The Centrality in Folkloristics of Motif and Tale Type." Journal of Folklore Research 34.3 (1997): 203-8. Print.

Granville-Barker, Harley. Prefaces to Shakespeare: Volume I: Hamlet, King Lear, The Merchant of Venice, Antony and Cleopatra, Cymbeline. London: B. T. Batsford, 1958. Print.

Hillman, Richard. Shakespearean Subversions: The Trickster and the Play-Text. London: Routledge, 1992. Print.

Hodgdon, Barbara, ed. The Taming of the Shrew. London: A \& C Black, 2012. Print.

Holmer, Joan Ozark. The Merchant of Venice: Choice, Hazard and Consequence. London: Macmillan Press, 1995. Print.

Hopkins, Lisa. "Marriage as Comic Closure." Shakespeare's Comedies. Ed. Smith, Emma. Malden: Blackwell Publishing, 2004. 36-54. Print.

---. The Shakespearean Marriage: Merry Wives and Heavy Husbands. London: Macmillan Press, 1998. Print.

Hunter, G. K., ed. All's Well That Ends Well. London: Cengage Learning, 2007. Print.

Ingram, Martin. Church Courts, Sex and Marriage in England, 1570-1640. Cambridge: Cambridge University Press, 1987. Print.

Kermode, Frank. The Age of Shakespeare. New York: Modern Library, 2004. Print.

Kinney, Arthur F., ed. The Oxford Handbook of Shakespeare. Oxford: Oxford University Press, 2012. Print. 
Kline, A. S. “Ovid's Metamorphoses.” Trans. Kline, Anthony S. Web. 19 December 2012. $<$ http://ovid.lib.virginia.edu/trans/Ovhome.htm>.

Laroque, François. "Shakespeare's Festive Comedies." A Companion to Shakespeare's Works, Volume III: The Comedies. Eds. Dutton, Richard and Jean E. Howard. Malden: Blackwell Publishing, 2003. 23-46. Print.

---. Shakespeare's Festive World: Elizabethan Seasonal Entertainment and the Professional Stage. Cambridge: Cambridge University Press, 1991. Print.

Lawrence, W. W. Shakespeare's Problem Comedies. New York: Frederick Ungar Publishing, 1960. Print.

Leggatt, Alexander. "All's Well That Ends Well: The Testing of Romance." Modern Language Quarterly 32.1 (1971): 21-41. Print.

---. ed. The Cambridge Companion to Shakespearean Comedy. Cambridge: Cambridge University Press, 2002. Print.

Lyon, John. Harvester New Critical Introductions to Shakespeare: "The Merchant of Venice". London: Harvester Wheatsheaf, 1988. Print.

Mikesell, Margaret Lael. "'Love Wrought these Miracles': Marriage and Genre in The Taming of the Shrew." The Taming of the Shrew: Critical Essays. Ed. Aspinall, Dana E. New York and London: Routledge, 2002. 106-29. Print.

Miola, Robert S. Shakespeare's Reading. Oxford: Oxford University Press, 2000. Print.

Muir, Kenneth. “Folklore and Shakespeare." Folklore 92.2 (1981): 231-40. Print.

Mukherji, Subha. "Consummation, Custom and Law in All's Well That Ends Well." Shakespeare and Sexuality. Eds. Alexander, Catherine M. S. and Stanley Wells. Cambridge: Cambridge University Press, 2001. 116-45. Print.

Neely, Carol Thomas. Broken Nuptials in Shakespeare's Plays. New Haven and London: Yale University Press, 1985. Print.

Newman, Karen. "Renaissance Family Politics and Shakespeare's The Taming of the Shrew." English Literary Renaissance 16.1 (1986): 86-100. Print.

O'Hara, Diana. Courtship and Constraint: Rethinking the Making of Marriage in Tudor England. Manchester: Manchester University Press, 2000. Print.

Oxford English Dictionary. Oxford University Press (2013). Web. <http://www.oed.com>.

Propp, V. Morphology of the Folktale. Trans. Scott, Laurence. Second ed. Austin and London: University of Texas press, 1968. Print. 
Raymond, Joad. "News." The Elizabethan World. Eds. Doran, Susan and Norman Jones. London and New York: Routledge, 2011. 495-510. Print.

Richardson, Catherine. "Domestic Life." The Oxford Handbook of Shakespeare. Ed. Kinney, Arthur F. Oxford: Oxford University Press, 2012. 202-18. Print.

Roberts, Jeanne Addison. "Horses and Hermaphrodites: Metamorphoses in The Taming of the Shrew." The Taming of the Shrew: Critical Essays. Ed. Aspinall, Dana E. New York and London: Routledge, 2002. 58-70. Print.

Schwarz, Kathryn. "'My Intents are Fix'd': Constant Will in All's Well That End Well." Shakespeare Quarterly 58.2 (2007): 200-27. Print.

Scragg, Leah. Shakespeare's Mouldy Tales: Recurrent Plot Motifs in Shakespearian Drama. London and New York: Longman, 1992. Print.

---. Shakespeare's Alternative Tales. Harlow: Addison Wesley Longman, 1996.

Shakespeare, William. All's Well That Ends Well. Ed. Hunter, G. K. London: Cengage Learning, 2007. Print.

---. The Merchant of Venice. Ed. Drakakis, John. London: Methuen Drama, 2010. Print.

---. The Taming of the Shrew. Ed. Hodgdon, Barbara. London: A \& C Black, 2010. Print.

Spencer, Christopher. The Genesis of Shakespeare's "Merchant of Venice". New York: Edwin Mellen Press, 1988. Print.

Stone, Lawrence. The Family, Sex and Marriage in England, 1500-1800. New York: Harper and Row, 1977. Web. 26 August 2012. <http://hdl.handle.net/2027/heb.01414>.

Stretton, Tim. "Women." The Elizabethan World. Eds. Doran, Susan and Norman Jones. London and New York: Routledge, 2011. 335-51. Print.

Thompson, Ann, ed. The Taming of Shrew. Cambridge: Cambridge University Press, 2003. Print.

Thompson, Stith. The Folktale. New York: Holt, Rinehart and Winston, 1946. Print.

---. Motif-Index of Folk Literature. CD-ROM ed. 1993.

---. Motif-Index of Folk Literature: A Classification of Narrative Elements in Folk Tales, Ballads, Myths, Fables, Mediaeval Romances, Exempla, Fabliaux, Jest-Books, and Local Legends. Bloomington: Indiana University Press, 1993. Web. 18 July 2011. $<$ www.ruthenia.ru/folklore/thompson/index.htm>.

Turner, Robert Y. "Dramatic Conventions in All's Well That Ends Well." Modern Language Association 75.5 (1960): 497-502. Print.

Walsham, Alexandra. "Reformed Folklore? Cautionary Tales and Oral Tradition in Early Modern England." The Spoken Word: Oral Culture in Britain, 1500-1850. Eds. Fox, 
Adam and Daniel Woolf. Manchester and New York: Manchester University Press, 2002. 173-95. Print.

Weimann, Robert. Shakespeare and the Popular Tradition in the Theatre: Studies in the Social Dimension of Dramatic Form and Function. Trans. Schwartz, Robert. Baltimore: John Hopkins University Press, 1978. Print.

Zitner, Sheldon P. Twayne's New Critical Introductions to Shakespeare: "All's Well That Ends Well". Boston: Twayne Publishers, 1989. Print. 